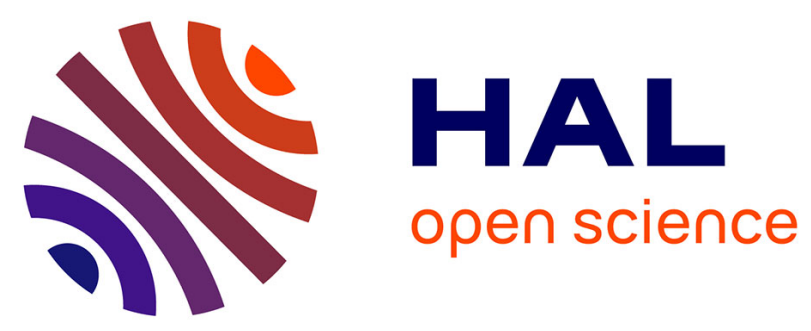

\title{
Selective extraction of neutral lipids and pigments from Nannochloropsis salina and Nannochloropsis maritima using supercritical CO2 extraction: Effects of process parameters and pre-treatment
}

Adil Mouahid, Kanitta Seengeon, Mathieu Martino, Christelle Crampon, Avery Kramer, Elisabeth Badens

\section{To cite this version:}

Adil Mouahid, Kanitta Seengeon, Mathieu Martino, Christelle Crampon, Avery Kramer, et al.. Selective extraction of neutral lipids and pigments from Nannochloropsis salina and Nannochloropsis maritima using supercritical CO2 extraction: Effects of process parameters and pre-treatment. Journal of Supercritical Fluids, 2020, 165, pp.104934. 10.1016/j.supflu.2020.104934 . hal-03232116

\author{
HAL Id: hal-03232116 \\ https://hal.science/hal-03232116
}

Submitted on 21 May 2021

HAL is a multi-disciplinary open access archive for the deposit and dissemination of scientific research documents, whether they are published or not. The documents may come from teaching and research institutions in France or abroad, or from public or private research centers.
L'archive ouverte pluridisciplinaire HAL, est destinée au dépôt et à la diffusion de documents scientifiques de niveau recherche, publiés ou non, émanant des établissements d'enseignement et de recherche français ou étrangers, des laboratoires publics ou privés. 


\title{
Selective extraction of neutral lipids and pigments from Nannochloropsis salina and Nannochloropsis maritima using supercritical $\mathrm{CO}_{2}$ extraction: Effects of process parameters and pre-treatment
}

\author{
Adil Mouahid $^{\mathrm{a}, *}$, Kanitta Seengeon ${ }^{\mathrm{a}}$, Mathieu Martino ${ }^{\mathrm{a}}$, Christelle Crampon ${ }^{\mathrm{a}}$, \\ ${\text { Avery } \text { Kramer }^{\mathrm{b}} \text {, Elisabeth Badens }}^{\mathrm{a}}$ \\ a Aix Marseille Univ, CNRS, Centrale Marseille, M2P2, Marseille, France \\ b Cellana, LLC, 590 Cypress Hills Drive, Encinitas, CA 92024, United States
}

\section{H I G H L I G H T S}

- The effects of process parameters on neutral lipids and pigments extractionfrom Nannochloropsis sp were investigated.

- Extraction kinetics were compared between air flow dried and ring dried biomass.

- RSM was used to investigate the effects of pressure and temperature on the recovery of neutral lipids and pigments.

- Sovová's mathematical was applied to better understand the mechanism of extraction kinetics.

\section{A R T I C L E I N F O}

Article history:

Available online 18 June 2020

Keywords:

Supercritical $\mathrm{CO}_{2}$ extraction

Ring dryer

Pigments

Sovová's model

Nannochloropsis, pre-treatment.
G R A P H I C A L A B S T R A C T

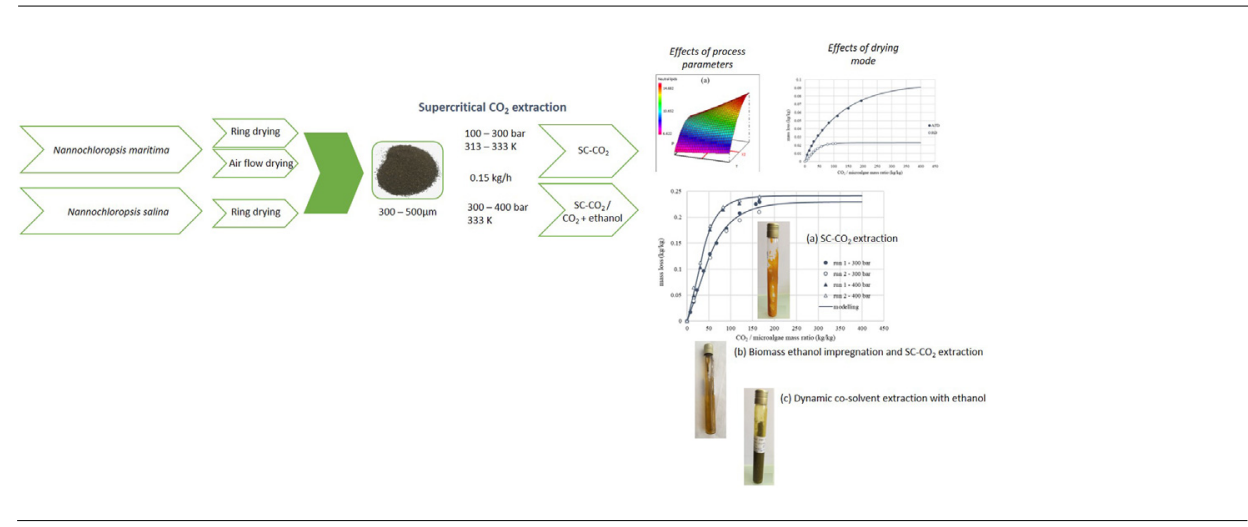

\begin{abstract}
A B S T R A C T
Supercritical $\mathrm{CO}_{2}$ extraction experiments were conducted to investigate the effects of pretreatment and process parameters on neutral lipids, chlorophylls and carotenoids recovery on two species of Nannochloropsis. For Nannochloropsis maritima, a factorial experimental design was performed (P: [100-300] bar, $\mathrm{T}$ : [313-333] K). The highest extraction yields were obtained at the highest pressures and temperatures. Two drying modes, ring drying and air flow drying, were compared. Although total extraction yield and extraction kinetics were observed to be greater using air flow dried microalgae, extracts from this drying method resulted in partial degradation of glycerides in free fatty acids. Ring dried extracts maintained the same neutral lipid composition as the initial biomass. Based on these results, ring dried Nannochloropsis salina was extracted using supercritical $\mathrm{CO}_{2}$ at $333 \mathrm{~K}$ and both $300-400$ bar. Extraction curves were modelled using the Sovová's mathematical model.
\end{abstract}

Abbreviations: AFD, Air flow drying / Air flow dried; Chl a, Chlorophyll $a$; DM, Dry matter; EPA, Eicosapentaenoic acid; FD, Freeze drying / Freeze Dried; FFA, Free fatty

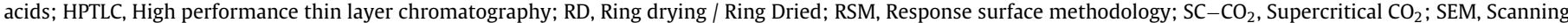
electron microscopy; TAG, Triacyl glycerides; TLC, Thin layer chromatography.

* Corresponding author.

E-mail address: adil.mouahid@univ-amu.fr (A. Mouahid). 


\begin{tabular}{|c|c|}
\hline \multicolumn{2}{|c|}{ Nomenclature } \\
\hline$A A R D$ & Average absolute relative deviation (\%) \\
\hline$a_{s}$ & $\begin{array}{l}\text { Specific area between the regions of intact and bro- } \\
\text { ken cells }\left(\mathrm{m}^{-1}\right)\end{array}$ \\
\hline$C_{u}$ & $\begin{array}{l}\text { Solute content in the untreated solid ( } \mathrm{kg} \text { solute } / \mathrm{kg} \\
\text { solid) }\end{array}$ \\
\hline$d_{p}$ & Microalgae particle diameter (m) \\
\hline$e$ & $\begin{array}{l}\text { Mathematical model extraction yield ( } \mathrm{kg} \text { extract } / \mathrm{kg} \\
\text { insoluble solid) }\end{array}$ \\
\hline$E$ & Amount extracted $(\mathrm{kg})$ \\
\hline$k_{S}$ & Solid-phase mass transfer coefficient (m/s) \\
\hline$n$ & Number of experimental points \\
\hline$N$ & Solid charge in the extractor $(\mathrm{kg})$ \\
\hline$N_{m}$ & Charge of insoluble solid (kg) \\
\hline$P$ & Pressure (bar) \\
\hline$q$ & $\begin{array}{l}\text { Relative amount of the passed solvent }\left(\mathrm{kg}_{\text {solvent }} / \mathrm{kg}\right. \\
\text { insoluble solid })\end{array}$ \\
\hline$\dot{Q}$ & $\mathrm{CO}_{2}$ flow rate $(\mathrm{kg} / \mathrm{s})$ \\
\hline$r$ & Grinding efficiency or fraction of broken cells \\
\hline$t$ & Extraction time (s) \\
\hline$T$ & Temperature (K) \\
\hline$x_{u}$ & $\begin{array}{l}\text { Concentration in the untreated solid ( } \mathrm{kg} \text { solute } / \mathrm{kg} \\
\text { insoluble solid) }\end{array}$ \\
\hline$y_{s}$ & Solute solubility ( $\mathrm{kg}$ solute $/ \mathrm{kg}$ solvent $)$ \\
\hline \multicolumn{2}{|c|}{ Greek letters } \\
\hline$\gamma$ & $\begin{array}{l}\text { Solvent to matrix ratio in the bed ( } \mathrm{kg} \text { solvent } / \mathrm{kg} \\
\text { insoluble solid) }\end{array}$ \\
\hline$\varepsilon$ & Bed void fraction \\
\hline
\end{tabular}

\section{Introduction}

Microalgal lipids and antioxidants are promising raw materials for the nutraceutical, food, energy, cosmetic and pharmaceutical industries [1]. Microalgal lipid composition varies between species and is also affected by growth conditions including medium composition, temperature, light intensity, and aeration rate [2]. Among microalgae species, Nannochloropsis species is very promising for several industrial applications and is considered a source of commercially valuable pigments [3-5]. Under ideal conditions it contains 25 up to $45 \%$ lipids that can be used as feedstock for biofuel production and the nutraceutical industry as both eicosapentaenoic acid (EPA) and other long chain triacylglycerides (TAGs) [1,2,6]. For these reasons, Nannochloropsis sp. were selected for this study.

Microalgal lipid extraction is typically performed using toxic and non-selective (polar and neutral lipids are both solubilized) organic solvents such as n-hexane. If industrially relevant fractions of the extracted oil are desired, additional separation steps are required. A widely reported [7-10] alternative to organic solvents is supercritical $\mathrm{CO}_{2}\left(\mathrm{SC}-\mathrm{CO}_{2}\right)$. There are several advantages of using $\mathrm{SC}-\mathrm{CO}_{2}$ including its selectivity of neutral lipids, its gaseous state at ambient pressure making it simple to remove residual solvent, and its recyclability. Algal $\mathrm{SC}-\mathrm{CO}_{2}$ extraction efficiency primarily depends on pre-treatment conditions. The first pretreatment step for an efficient extraction is dewatering (solar drying, air flow drying, freeze drying, microwave, ...) followed by the increase of the cracking of specific surface area by mechanical methods (bead milling, ultra-sonication, ....). Non-mechanical methods like chemical cell disruption or enzymatic cell hydrolysis can be applied for helping the release of solutes of interest and their further recovery during extraction. Extraction efficiency also depends on free solute accessibility and internal diffusion (choice of process parameters and/or the use of co-solvent) [7,10-14].
A summary of recent studies dealing with the $\mathrm{SC}-\mathrm{CO}_{2}$ extraction of neutral lipids and valuable compounds from Nannochloropsis species $[4,11,15-25]$ are reported in Table 1 . Although a detailed and accurate comparison between these studies is difficult due to the range of different Nannochloropsis strains, growing conditions, pre-treatments, and extraction conditions $\left(\mathrm{CO}_{2}\right.$ flow rate, particle size diameter, initial water content, etc.). Some interesting tendencies can be highlighted. Studies dealing with the pretreatment effects on the extraction kinetics and efficiency $[11,17,25]$ showed that air flow drying (AFD) was the most suitable drying mode leading to high extraction kinetics of neutral lipids in comparison to freeze drying (FD). Indeed, FD preserves the integrity of the microalga cell membranes and thus induces more limitation for diffusion leading to slower extraction kinetics. Adding distilled water to dried $N$. oculata to moisture contents up to $20 \mathrm{wt} \%$ seems to have no influence on the oil extraction yields [11]. Extracts contained both oil and water. Another pretreatment recently investigated suggests that cell wall damage of marine Nannochloropsis sp. caused by an osmotic gradient can have a positive effect on $\mathrm{SC}-\mathrm{CO}_{2}$ extraction kinetics with ethanol as co-solvent [25]. Performing one to three consecutive washing steps with distilled water created an osmotic pressure imbalance across the cell wall prior to FD. The authors showed that the pretreatment doubled the total extraction yield while increasing the concentration of acylglycerides and free fatty acids. Nevertheless, hydrolysis of glycerides was observed probably due to the pretreatment washing procedure.

Studies reporting the effects of process parameters $[4,15,16,18,21,22]$ showed that when FD was performed, the highest extraction kinetics were obtained for pressures higher than 300 bar and temperatures close to $323 \mathrm{~K}$. The highest extracted amount of chlorophyll $a(\mathrm{Chl}$ a) and total carotenoids with pure $\mathrm{SC}-\mathrm{CO}_{2}$ was obtained at 400 bar and $60^{\circ} \mathrm{C}$. The highest carotenoids/Chl a concentration ratio was obtained at $200 \mathrm{bar}$

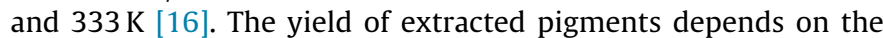
operating conditions (influencing the $\mathrm{SC}-\mathrm{CO}_{2}$ density and the pigment vapor pressure) and on the nature of the other extracted compounds that can play the role of co-solvents [18].

When the effects of co-solvents were investigated [4,19,22-25], it was possible to observe that ethanol was the most appropriate co-solvent when pigments (chlorophyll, carotenoids, ... .) were targeted. The yield of extraction depended strongly on the $\mathrm{SC}-\mathrm{CO}_{2}$ density and the amount of ethanol introduced [4]. When acetone was used as co-solvent, the extraction yield and lipidic extract composition weren't significantly enhanced compared to the extraction with pure $\mathrm{SC}-\mathrm{CO}_{2}$ at 320 bar and $313 \mathrm{~K}$ [19]. Furthermore, no significant difference was found in the fatty acids profile. Azeotropic mixture (Hexane/Ethanol) helped to extract a high amount of neutral and polar lipids but also EPA at 340 bar and $353 \mathrm{~K}$ when microwave pretreatment was applied to the dried raw biomass to enhance the cell disruption [24].

A review of the studies reported in Table 1 offers insights but also identifies gaps in the consistency of reported information (particle size diameter, initial water content, description of drying method, ...). These missing data are of prime importance for comparison purposes and scale up studies. Few studies report pretreatment conditions such as drying treatment mode and effects of high water-COntent. Finally, the extraction of pigments was mainly investigated using a co-solvent. Additional $\mathrm{SC}-\mathrm{CO}_{2}$ investigations are needed to fill these gaps so industrial scale-up of this technology can be realized.

The goal of this study is to deepen the studies on the $\mathrm{SC}-\mathrm{CO}_{2}$ extraction of valuable compounds (neutral lipids, chlorophyll and total carotenoids) from Nannochloropsis species by investigating the effects of operating parameters (pressure, temperature), pretreatment (drying mode and effects of high water content) with pure $\mathrm{SC}-\mathrm{CO}_{2}$ and ethanol as co-solvent. Two species of 
Table 1

Main recent studies related to the $\mathrm{SC}-\mathrm{CO}_{2}$ extraction of valuable compounds from Nannochloropsis species.

\begin{tabular}{|c|c|c|c|c|c|c|c|c|}
\hline \multicolumn{9}{|c|}{ Extraction with pure $\mathrm{SC}-\mathrm{CO}_{2}$} \\
\hline Microalgae & pre-treatments / particle size & $\mathrm{P}($ bar $)$ & $\mathrm{T}(\mathrm{K})$ & $\mathrm{CO}_{2}$ flow rate & $\begin{array}{l}\text { Extraction time } \\
\text { (h) }\end{array}$ & $\begin{array}{l}\text { Major } \\
\text { extracted } \\
\text { compounds }\end{array}$ & Best yield / goal & References \\
\hline Nannochloropsis sp. & FD, $d_{p}=370 \mu \mathrm{m}$ & $400,500,700$ & 313,328 & $10 \mathrm{~kg} / \mathrm{h}$ & 6 & $\begin{array}{l}\text { C16:0, } \\
\text { C16:1:n-7, EPA }\end{array}$ & $\begin{array}{l}\text { Highest extraction yield: } 25 \% \text { at } \\
700 \text { bar and } 328 \mathrm{~K} / \text { Investigate the } \\
\text { effects of the operating conditions } \\
\text { on extraction kinetics, yield and } \\
\text { fatty acid composition. }\end{array}$ & [15] \\
\hline $\begin{array}{l}\text { Nannochloropsis } \\
\text { gaditana }\end{array}$ & FD & $\begin{array}{l}100,200,300 \\
400,500\end{array}$ & $313,323,333$ & $0.012 \mathrm{~kg} / \mathrm{h}$ & 3 & $\begin{array}{l}\text { Chl a, } \\
\text { carotenoids }\end{array}$ & $\begin{array}{l}\text { Highest extraction yield at } 400 \mathrm{bar} \\
\text { and } 333 \mathrm{~K} / \text { The aim was to } \\
\text { ascertain the influence of pressure } \\
\text { and temperature on } \mathrm{SC}^{-} \mathrm{CO}_{2} \\
\text { extraction of } \mathrm{Chl} \text { a and carotenoids. }\end{array}$ & [16] \\
\hline Nannochloropsis sp. & $\begin{array}{l}\text { Oven drying at } 343 \mathrm{~K} \\
\text { Grinding }\end{array}$ & $125,200,300$ & 313,333 & $\begin{array}{l}0.021, \\
0.037 \mathrm{~kg} / \mathrm{h}\end{array}$ & - & Neutral lipids & $\begin{array}{l}\text { Best extraction yield: } 33 \% \text { at } \\
300 \text { bar, } 313 \mathrm{~K} \text { and } 0.037 \mathrm{~kg} / \mathrm{h} \text { / The } \\
\text { aim was to use the biomass and } \\
\text { apply biorefinery approach for the } \\
\text { production of oil, high added-value } \\
\text { compounds and biohydrogen. }\end{array}$ & [4] \\
\hline $\begin{array}{l}\text { Nannochloropsis } \\
\text { oculata }\end{array}$ & $\begin{array}{l}\text { AFD at } 308 \mathrm{~K} \text {, FD water content } \\
4-5 \mathrm{wt} \% \text { and } 20 \mathrm{wt} \% \mathrm{~d}_{\mathrm{p}}<160 \mu \mathrm{m} \text {, } \\
d_{\mathrm{p}}=315-1000 \mu \mathrm{m}\end{array}$ & 400 & 333 & $0.5 \mathrm{~kg} / \mathrm{h}$ & - & 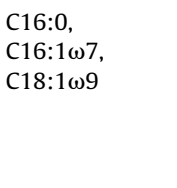 & $\begin{array}{l}\text { Extraction yield: } 12 \% \text { for AFD and } \\
d_{p}<160 \mu \mathrm{m} / \text { Investigate the effects } \\
\text { of high water-content, drying } \\
\text { mode and particle size on extract } \\
\text { composition and extraction } \\
\text { kinetics }\end{array}$ & [11] \\
\hline $\begin{array}{l}\text { Nannochloropsis } \\
\text { oculata }\end{array}$ & $\begin{array}{l}\text { AFD at } 308 \mathrm{~K}, \mathrm{FD} \\
\text { water content } 4-5 \mathrm{wt} \% \text { and } 20 \mathrm{wt} \% \\
d_{p}<160 \mu \mathrm{m}, \mathrm{d}_{\mathrm{p}}=315-1000 \mu \mathrm{m} \\
\text { nitrogen limitation culture }\end{array}$ & 400 & 333 & $0.4,0.5 \mathrm{~kg} / \mathrm{h}$ & - & 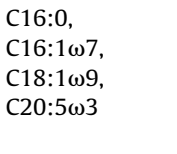 & $\begin{array}{l}\text { Extraction yield: } 30 \% \text { for AFD, } \\
\text { nitrogen limitation culture and } \\
d_{p}=160-315 \mu \mathrm{m} / \text { Investigate the } \\
\text { effects of pre-treatment on } \\
\text { extraction kinetics and modelling. }\end{array}$ & [17] \\
\hline $\begin{array}{l}\text { Nannochloropsis } \\
\text { gaditana }\end{array}$ & $\begin{array}{l}d_{p}=616 \mu \mathrm{m}, \text { water content of } \\
30 \mathrm{wt} \%\end{array}$ & $\begin{array}{l}317,377,381 \\
425,464,479 \\
533,543\end{array}$ & $\begin{array}{l}309,313,323 \\
333,337\end{array}$ & & 1.2 & $\begin{array}{l}\text { Carotenoids, } \\
\text { tocopherol, } \\
\text { C16:0, C16:1, } \\
\text { C18:1, EPA }\end{array}$ & $\begin{array}{l}\text { Best extraction conditions for } \\
\text { carotenoids: } 533 \text { bar and } 337 \mathrm{~K} / \\
\text { Study of the effects of temperature } \\
\text { and } \mathrm{CO}_{2} \text { density on the content of } \\
\text { carotenoids and tocopherols. }\end{array}$ & [18] \\
\hline $\begin{array}{l}\text { Nannochloropsis } \\
\text { salina }\end{array}$ & $\begin{array}{l}\text { Drying at atmospheric pressure } \\
\text { and temperature }(298 \mathrm{~K}) \text { for } 16 \mathrm{~h} \text {, } \\
\text { Water content of } 4.12 \mathrm{wt} \% \text {, } \\
d_{p}=500-1000 \mu \mathrm{m}\end{array}$ & 320 & 313 & $1.5 \mathrm{~kg} / \mathrm{h}$ & - & $\begin{array}{l}\text { Palmitoleic } \\
\text { acid, Palmitic } \\
\text { acid, Oleic acid, } \\
\text { EPA }\end{array}$ & $\begin{array}{l}\text { Extraction yield: } 6.25 \% \text { / } \\
\text { Investigate the extraction of lipids } \\
\text { and valuable compounds from } \\
\text { microalgae. }\end{array}$ & [19] \\
\hline $\begin{array}{l}\text { Nannochloropsis } \\
\text { oculata }\end{array}$ & $\begin{array}{l}\text { Washed with ammonium formate } \\
\text { to remove salt, dried in a } \\
\text { dehydrator at } 318 \mathrm{~K} \text { during } 40 \mathrm{~h}\end{array}$ & 300 & 313 & $9 \mathrm{~mL} / \mathrm{min}$ & 2 & $\begin{array}{l}\text { C16:0, C16:1, } \\
\text { EPA, total } \\
\text { carotenoids }\end{array}$ & $\begin{array}{l}\text { Extraction yield: } 15.6 \% \text { / } \\
\text { Comparison of fatty acid } \\
\text { composition, total carotenoids and } \\
\text { antioxidants with sub-critical } \\
\text { n-butane extraction. }\end{array}$ & [20] \\
\hline
\end{tabular}


Table 1 (Continued)

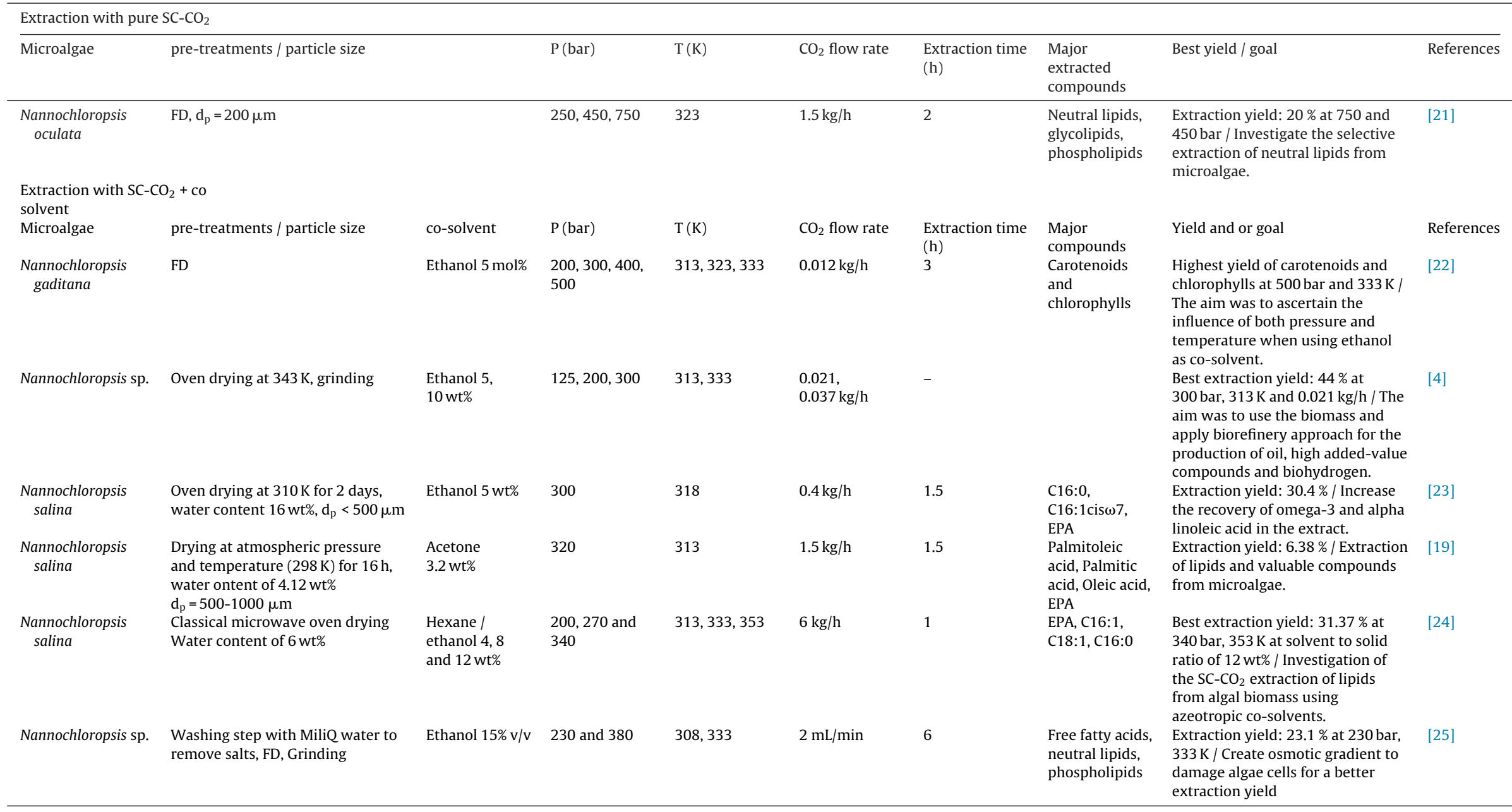


Nannochloropsis were considered: Nannochloropsis maritima ( $N$. maritima) and Nannochloropsis salina (N. salina). To our knowledge, no SC $-\mathrm{CO}_{2}$ extraction experiments have been reported on $\mathrm{N}$. maritima. The effects of extraction process parameters using pure $\mathrm{SC}-\mathrm{CO}_{2}$ (AFD pretreatment) on N. maritima using Response Surface Methodology (RSM) was investigated. To complete the studies reporting effects of drying mode on microalgae [10,11,17], the effects of a new drying mode was investigated with ring drying (RD) as a viable pretreatment option. A ring dryer is an industrialscale, pneumatic system that was developed to increase versatility of flash drying technology. RD is described in detail in the following references [26-28]. It is used in a number of industries and operates by exposing a slurry to superheated air in a circular form factor that facilitates controlled drying conditions and prevents overheating of the final product. Drying time is significantly shorter than AFD (a few seconds versus several hours) and thus limits the risk of lipid degradation. To our knowledge, this drying mode has not been reported for $\mathrm{SC}-\mathrm{CO}_{2}$ extraction in the literature. The $\mathrm{SC}-\mathrm{CO}_{2}$ extraction of valuable compounds from RD $N$. salina was investigated with pure $\mathrm{CO}_{2}$ and with ethanol as co-solvent. A new method to disrupt cell walls by impregnating dried microalgae with ethanol was performed. The effect of a high-water content of the biomass on the extraction kinetics and extracted compounds was also investigated. Experimental extraction curves were modelled using Sovová's broken and intact cell (BIC) mathematical model to better understand the mechanism of extraction kinetics.

\section{Materials and methods}

\section{Raw materials and chemicals}

Nannochloropsis samples were provided by Cellana LLC (Hawaii, USA). The algae cultures were grown in outdoor conditions, harvested, and thickened to $22 \%$ solids with a Westfalia disk stack centrifuge. $N$. maritima samples were provided both as ring dried (RD) material and as wet paste material. $N$. salina samples were provided as RD material. The ring dryer used in this study operated at $353 \mathrm{~K}$ and the average retention time was less than $30 \mathrm{~s}$. The wet paste was air flow dried (AFD) in a circulating air oven (classical plant dryer) SFP 6 type (R.E.U.S France) which was set to the optimum conditions of $308 \mathrm{~K}$ for $20 \mathrm{~h}$ according to a previous study [10]. The final water content of the resulting samples was about $13 \mathrm{wt} \%$ and about $3.4 \mathrm{wt} \%$ for AFD and RD biomass respectively. The dried biomass was ground into powder and sized into homogenous particle size ranges with a vibratory sieve shaker at a mean particle size of $300-500 \mu \mathrm{m}$. Algae powder was stored at $277 \mathrm{~K}$ prior to experiments to avoid degradation of the compounds. $\mathrm{SC}-\mathrm{CO}_{2}$ extraction experiments were carried out with carbon dioxide of 99.7\% purity supplied by Air Liquide Méditerranée (France). Absolute ethanol with a purity of $99.8 \%$, used as co-solvent, was supplied by Fisher (France).

\section{Experimental setup}

The process diagram of the experimental setup is given in

Fig. 1 Extractions were performed using laboratory scale equipment provided by SEPAREX (Champigneulles, France). The $\mathrm{CO}_{2}$ high pressure pump (3) used for this study was a high-pressure liquid $\mathrm{CO}_{2}$ pump Jasco PU-4386 (Jasco France). A high-pressure solvent pump (10), GILSON 307 Pump with standard head pump of 5SC type (Gilson Inc., USA), was connected to the extraction pilot in order to clean the pipes and the micrometric valve (V3) at the end of each experiment or for co-solvent extractions. All experiments were carried out in a $10 \mathrm{~cm}^{3}$ extraction vessel (6) filled to a vol- ume of $80 \%$, which corresponded to a sample mass of $5 \mathrm{~g}$ for each experiment.

Considering the small charges of biomass in the extraction vessel, the amount of extracted neutral lipids $E$ was calculated considering the mass losses of the extraction autoclave. Weight losses were recorded prior to extraction and $30 \mathrm{~min}$ after extraction to allow liberation of residual $\mathrm{CO}_{2}$. Extract samples were recovered in glass vessels which were subsequently topped with nitrogen and stored at $255 \mathrm{~K}$ until compositional analysis. The yield was expressed as the mass ratio of the sample mass loss $(E)$ to the mass introduced initially in the extraction autoclave $(N)$. This yield was assimilated to neutral lipids yield since it is well known that $\mathrm{SC}-\mathrm{CO}_{2}$ solubilizes non polar-lipids.

Extraction experiments with pure $\mathrm{CO}_{2}$ were conducted with valves $\mathrm{V} 4$ and $\mathrm{V} 5$ closed. The $\mathrm{CO}_{2}$ flow and pressure were controlled with micrometric valve $\mathrm{V} 3$. The $\mathrm{CO}_{2}$ flowrate was measured thanks to a flowmeter located at the end of the extraction line (8). When the extraction experiments were completed, pipes and micrometric valve were washed with absolute ethanol by closing valve V2 and opening valve V4. The apparatus was then dried with a flow of gaseous $\mathrm{CO}_{2}$ during a few minutes (Valves V2, V3 and V5 open, valve V4 closed).

For experiments with co-solvent, absolute ethanol was added at system pressure to $\mathrm{SC}-\mathrm{CO}_{2}$ via a union tee $\left(1 / 8^{\prime \prime}\right)$ prior to the extraction vessel (blue line in

Fig. 1). Only a qualitative evaluation of the extraction is made by analyzing the extract composition. Co-solvent experiments were conducted for $3 \mathrm{~h}$ and the extracts were analyzed for composition as described below.

\section{Experiments performed on N. Maritima}

Extraction experiments performed on dried N. maritima were conducted without co-solvent at a constant $\mathrm{CO}_{2}$ flow rate of $0.15 \mathrm{~kg} / \mathrm{h}$. The effects of pressure and temperature on the yield of extracted neutral lipids, on $\mathrm{Chl}$ a and total carotenoids concentration in the extracts at a $\mathrm{CO}_{2} /$ microalgae mass ratio of $180 \mathrm{~kg} / \mathrm{kg}$ were investigated using Response Surface Methodology (RSM). Three levels were considered for the pressure and the temperature $(-1,0,1$ respectively for pressures of 100,200 and $300 \mathrm{bar}$ and temperatures of 313,323 and $333 \mathrm{~K}$ ). The degree of significance of each factor ( $p$-value) was given by NemrodW software and was discussed. A classical plan composed of 9 experiments was considered. Each response Y (neutral lipids yield, chlorophyll $a$ concentration and total carotenoids concentration) was modelled using a second-order polynomial model given in Eq. 1.

$\mathrm{Y}=\mathrm{b}_{0}+\mathrm{b}_{1} \mathrm{P}+\mathrm{b}_{2} \mathrm{~T}+\mathrm{b}_{11} \mathrm{P}^{2}+\mathrm{b}_{22} \mathrm{~T}^{2}+\mathrm{b}_{12}$.T.P

Where $b_{0}, b_{1}, b_{2}, b_{11}, b_{22}, b_{12}$ are the coefficient of the response surface equation calculated by NemrodW software (LPRAI, Marseille, France).

The effect of drying mode on extraction kinetics was investigated at 100 bar and $313 \mathrm{~K}$.

All experimental conditions were summarized in Table 2.

\section{Experiments performed on N. Salina}

$\mathrm{SC}-\mathrm{CO}_{2}$ extraction experiments on $\mathrm{RD}$ N. salina were performed at pressures of 300 and $400 \mathrm{bar}$, a temperature of $333 \mathrm{~K}$ and a $\mathrm{CO}_{2}$ flow rate of $0.15 \mathrm{~kg} / \mathrm{h}$ with pure $\mathrm{CO}_{2}$, ethanol as co-solvent and with biomass at high water content. The operating conditions were chosen by building on the previous reported study [22]. All experiments performed on RD N. salina were reported in Table 2.

Two kinds of experiments were performed using ethanol as cosolvent. The first experiment consisted in impregnating the ground and sieved microalgae with absolute ethanol for $24 \mathrm{~h}$. The biomass 


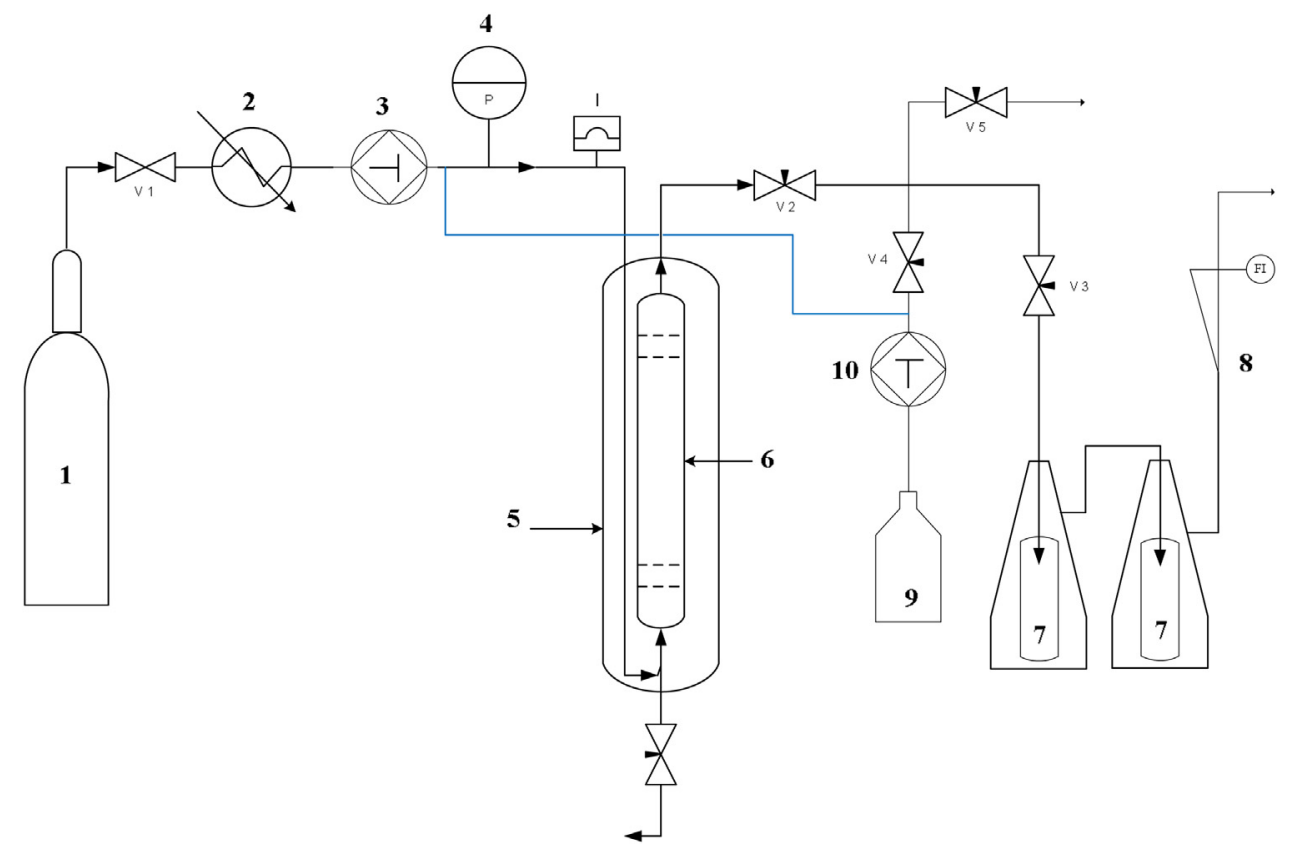

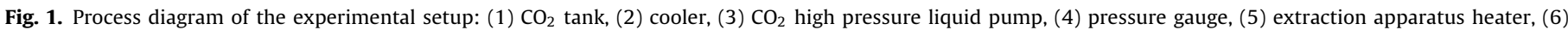
extraction vessel, (7) glass vessel, (8) flowmeter, (9) ethanol tank, (10) Gilson high pressure solvent pump.

Table 2

Summary of experimental conditions.

\begin{tabular}{|c|c|c|c|c|c|c|c|}
\hline \multirow[b]{2}{*}{ Strain } & \multirow[b]{2}{*}{ Drying mode } & \multirow[b]{2}{*}{ Initial water content (wt \%) } & \multicolumn{5}{|c|}{ Extraction conditions } \\
\hline & & & Co-solvent & 100 bar & 200 bar & 300 bar & 400 bar \\
\hline \multirow{4}{*}{$\begin{array}{l}N . \\
\text { mar- } \\
\text { itima }\end{array}$} & \multirow{3}{*}{ AFD } & \multirow{3}{*}{13} & \multirow{3}{*}{-} & $313 \mathrm{~K}$ & $313 \mathrm{~K}$ & $313 \mathrm{~K}$ & \multirow{3}{*}{-} \\
\hline & & & & $323 \mathrm{~K}$ & $323 \mathrm{~K}$ & $323 \mathrm{~K}$ & \\
\hline & & & & $333 \mathrm{~K}$ & $333 \mathrm{~K}$ & $333 \mathrm{~K}$ & \\
\hline & $\mathrm{RD}$ & 3.4 & - & $313 \mathrm{~K}$ & - & - & - \\
\hline \multirow{3}{*}{$\begin{array}{l}N . \\
\text { salina }\end{array}$} & \multirow{3}{*}{$\mathrm{RD}$} & 3.4 & - & - & - & $333 \mathrm{~K}$ & $333 \mathrm{~K}$ \\
\hline & & 23.9 & - & - & - & - & $333 \mathrm{~K}$ \\
\hline & & 3.4 & Ethanol $^{\mathrm{a}}$ & - & - & $333 \mathrm{~K}$ & - \\
\hline
\end{tabular}

a Two ethanol co-solvent conditions: maceration $(24 \mathrm{~h})$ and in-line with SC- $\mathrm{CO}_{2}(4.3 \% \mathrm{wt} / \mathrm{wt})$.

was then introduced in the extraction vessel to perform $\mathrm{SC}-\mathrm{CO}_{2}$ extraction. The ethanol:biomass mass ratio was $2: 5$ (wt/wt). In the second experiment, the co-solvent was pumped by a high-pressure pump (Gilson 307) and mixed with the pressurized $\mathrm{CO}_{2}$ flow before entering the extraction vessel.

To deepen the study about the effects of water on extraction kinetics and on extract composition, distilled water was added to RD N. salina samples. An amount of $5 \mathrm{~g}$ of ground and sieved powder of microalgae was introduced in a sealed vessel filled with distilled water until the desired water content was reached. The water content was increased from $3.4 \mathrm{wt} \%$ to $23.9 \mathrm{wt} \%$.

\section{Analytical methods}

\section{Neutral and polar lipids}

Extracts were analyzed for determining lipidic profiles as follows: $1-5 \mathrm{mg}$ samples were diluted in a solution of chloroform:methanol (2:1) to a concentration of $1 \mathrm{mg} / \mathrm{mL}$ and stored at $253 \mathrm{~K}$ until analysis. High Performance Thin Layer Chromatography (HPTLC) analysis of the lipids content was performed by ATS4 spray deposition on a Merck 60 silica gel followed by ADC2 development at $70 \mathrm{~mm}$. Samples were dissolved in a $\mathrm{n}$ hexane:diethyl ether:acetic acid (17:3:0.2) solution for neutral lipid analysis and in a acetone:toluene:water (91:30:8) solution for polar lipids. Revelation was carried out by immersion in a copper sulfate/orthophosphoric acid solution at $443 \mathrm{~K}$ for $20 \mathrm{~min}$. Spectral analysis was performed on a TLC scanner 3 at $500 \mathrm{~nm}$. Monitoring and data treatment were completed using Wincat software.

Gas Chromatography Mass Spectrometry (GC-MS) analysis of the composition in Fatty Acid Methyl Esters (FAME) was carried out using an Agilent GC equipped with a ZB-WAX $(0.25 \mathrm{~m} \times 30 \mathrm{~m})$ column, $\mathrm{H}_{2}$ as a carrier gas - split mode on two detectors. Prior to analysis, a trans-methylation was carried out in a solution of methanol / sulfuric acid $5 \%(1.5 \mathrm{~h} ; 358 \mathrm{~K})$ followed by extraction with n-hexane. Quantification was completed using Flame Ionization Detection (FID) and mass spectroscopy. Calibration was performed with standards ranging from C14 to C24.

\section{Chlorophyll a and total carotenoids}

Total carotenoids and chl a concentration was carried out by measuring the absorbance of extract samples diluted in pure acetone using a Jenway $6715 \mathrm{UV} / \mathrm{vis}$ spectrophotometer. The correlations proposed by Lichtenthaler et al. [29], given in Eq. 2 to 4, were used in this study. Before absorbance measurements of extract, a blank measure was made with pure acetone.

$\mathrm{C}_{\mathrm{a}}(\mu \mathrm{g} / \mathrm{mL})=11.24 \mathrm{~A}_{661.6}-2.04 \mathrm{~A}_{644.8}$

Where $C_{a}$ is the concentration of chlorophyll $a(\mathrm{Chl} \mathrm{a}), A_{661.6}$ the absorbance (arbitrary unit) at the wavelength of $661.6 \mathrm{~nm}$ 
and $\mathrm{A}_{644.8}$ is the absorbance (arbitrary unit) at the wavelength of $644.8 \mathrm{~nm}$.

$\mathrm{C}_{\mathrm{b}}(\mu \mathrm{g} / \mathrm{mL})=20.13 \mathrm{~A}_{644.8}-4.19 \mathrm{~A}_{661.6}$

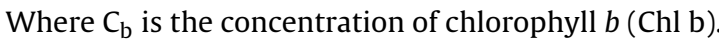

Finally, the concentration in carotenoids is estimated using the following expression:

$\mathrm{C}_{\text {totalcarotenoids }(\mathrm{x}+\mathrm{c})}(\mu \mathrm{g} / \mathrm{mL})=\left(1000 \mathrm{~A}_{470}-1.9 \mathrm{C}_{\mathrm{a}}-63.14 \mathrm{C}_{\mathrm{b}}\right) / 214$

The diluted solutions composed of the extracts in acetone must be fully transparent as a turbid solution leads to a higher absorption between 400 and $800 \mathrm{~nm}$. This higher absorption would give an overestimation of the pigment level especially for $\mathrm{Chl} \mathrm{b}$ and total carotenoids. Hence, turbidity must be checked by measuring the absorbance at $750 \mathrm{~nm}\left(\mathrm{~A}_{750}\right)$. For a fully transparent extract, $\mathrm{A}_{750}$ should equal zero since $\mathrm{Chl} \mathrm{a}$ and $\mathrm{b}$ and carotenoids do not absorb in this region. Analysis showed that the studied strains do not contain $\mathrm{Chl} b$ which is in accordance with studies reporting that Nannochloropsis contains mainly $\mathrm{Chl}$ a and carotenoids (violaxanthin) [3,4]. The concentrations of each pigment (Eqs. 2 - 4) were expressed for a solvent volume of $5 \mathrm{~mL}$ [30]. In this study, the results were expressed in $\mu$ g of pigment / g of dry microalga $(N)$.

\section{Scanning electron microscopy (SEM)}

Samples of N. maritima and salina were observed with a Scanning Electron Microscope. The visualizations were made on a Hitachi TM3000 Tabletop Microscope $(15 \mathrm{kV})$. The sample powders of microalgae were deposited on an adhesive pastille and metallized with a thin layer of Au-Pd to allow better sample conduction and visualization. The metallization time did not exceed $30 \mathrm{~s}$.

\section{Modelling of the extraction curves}

The extraction curves were modelled using Sovová's mathematical model for supercritical fluid extraction of natural products [31]. This model takes into account the structure of the biological material studied and accounts for the sudden reduction in extraction rate after the first extraction period that is observed during $\mathrm{SC}-\mathrm{CO}_{2}$ extractions from seeds. This model was already applied to describe the extraction curves obtained from microalgae [10,17,23]. Four types of extraction curves can be found: A, B, C or D. In the decision on extraction type one can refer to the shape of the extraction curves as shown in Fig. 2. If the first part of the extraction curve consists of one straight section, the type is A or D. If it consists of two straight sections, it is of type B or C.

In this study, the first part of the extraction consists of one straight section. Hence, the type can be A or D. The slope of the first part of the curve is related to solute solubility for type A while it is lower than solute solubility for type D.

Experiments were performed to estimate the solute solubility in $\mathrm{SC}-\mathrm{CO}_{2}$ at the operating conditions for N. maritima and N. salina based on the methodology proposed by Perrut et al. [32]. Extracted solute was spread on glass beads (diameter of about $200 \mu \mathrm{m}$ ) and $\mathrm{SC}-\mathrm{CO}_{2}$ extraction was performed at the same operating condition with a $\mathrm{CO}_{2}$ flow rate of $0.02 \mathrm{~kg} / \mathrm{h}$ for $80 \mathrm{~min}$ to ensure fluid phase equilibrium in the system. It appears that the slope of the extraction curve at initial time was related to the solute solubility whatever the drying mode. These observations lead to the selection of type A.

The flow pattern was assumed to be plug flow. The bed void fraction $\varepsilon$ of $N$. maritima is 0.379 and 0.497 for AFD and RD biomass respectively and 0.295 for RD N. salina. The methodology for the determination of $\varepsilon$ and plug flow assumption was already described in details in previous work [17]. The type A extraction curve can be described by considering Eq. 5 and 6 (the model parameters are described in the nomenclature):

\section{First extraction period}

$e=q y_{s}$ for $0 \leq \mathrm{q} \leq \mathrm{q} 1$

Second extraction period

$e=x_{u}\left[1-C_{1} \exp \left(-C_{2} q\right)\right]$ for $\mathrm{q}>\mathrm{q} 1$

With:

$r=1-C_{1} \exp \left(\frac{-C_{2} q_{1}}{2}\right)$

$k_{s} a_{s}=(1-r)(1-\varepsilon) \frac{\dot{Q} C_{2}}{N_{m}}$

$e=\frac{E}{N_{m}}$

$q=\frac{\dot{Q} t}{N_{m}}$

$N_{m}=\left(1-C_{u} N\right)$

$C_{u}=\frac{x_{u}}{1+x_{u}}$

For the first part of the extraction curve $\left(0 \leq q \leq q_{1}\right.$, where $q_{1}$ represents the end of the first extraction period), the slope $y_{s}$ value, which represents the extracted solute solubility, was chosen according to the solubility determination previously described. The second extraction period $\left(q>q_{1}\right)$ is described by adjusting constant parameters $C_{1}$ and $C_{2}$ on experimental data. Estimations of parameters $k_{s} a_{s}$ and $r$ can then be obtained by considering Eq. 7 to 12 . The adjustable parameters $C_{1}$ and $C_{2}$ were calculated by minimizing the sum of least squares between the experimental and calculated values of $e$. The average absolute relative deviation (AARD) given in Eq. 13, was used to evaluate the efficiency of the model.

$A A R D(\%)=\frac{100}{n} \sum\left|\frac{\text { Experimental yield }- \text { Calculated yield }}{\text { Experimental yield }}\right|$

The modelled extraction curves were expressed as the variation of the yield (mass ratio of the sample mass loss to the mass introduced initially in the extraction autoclave) as function of the $\mathrm{CO}_{2}$ / microalgae mass ratio $(\dot{Q} \times t / N)$.

\section{Results and discussions}

\section{Extraction of valuable compounds from AFD N. Maritima}

\section{Effects of process parameters}

Prior to $\mathrm{SC}-\mathrm{CO}_{2}$ extraction, a repeatability test (Fig. 3) was performed on AFD biomass at 300 bar and $333 \mathrm{~K}$. The average deviation between the two sets of experiments is about $5.9 \%$ which is satisfactory. The shape of the curve shows a nearly complete extraction with a yield of $14.5 \%$ using a $\mathrm{CO}_{2} /$ microalgae mass ratio of $180 \mathrm{~kg} / \mathrm{kg}$. The modelled curve confirms this observation, the increase in the extracted amount of solute is extremely low from $180 \mathrm{~kg} / \mathrm{kg}$ up to $400 \mathrm{~kg} / \mathrm{kg}$.

The effects of operating conditions on the neutral lipid yield (Fig. 4 (a)), Chl a (Fig. 4 (b)) and total carotenoid (Fig. 4 (c)) concentration at a $\mathrm{CO}_{2} /$ microalgae mass ratio of $180 \mathrm{~kg} / \mathrm{kg}$ have been reported in Fig. 4.

The polynomial coefficients of Eq. 4 are reported in Table 3. The degree of significance of each factor (pressure, temperature) is represented in Table 3 by its p-value in \%. When a factor has a p-value lower than $5 \%$, it influences the process in a statistically significant way. 


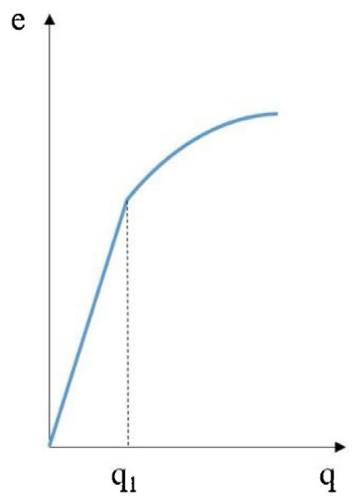

Type A

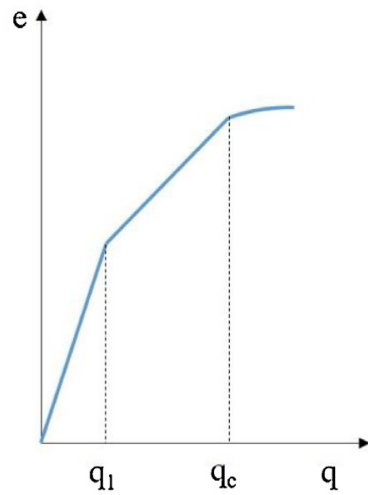

Type B

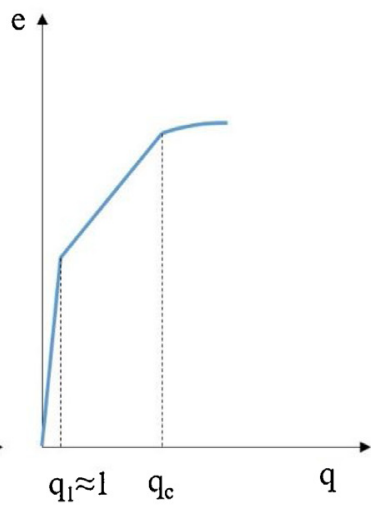

Type C

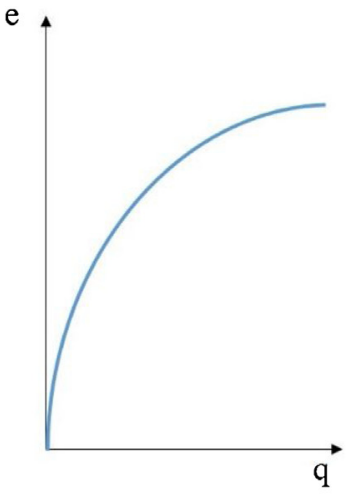

Type D

Fig. 2. Aspects of the type of extraction curves according to Sovová's mathematical model.

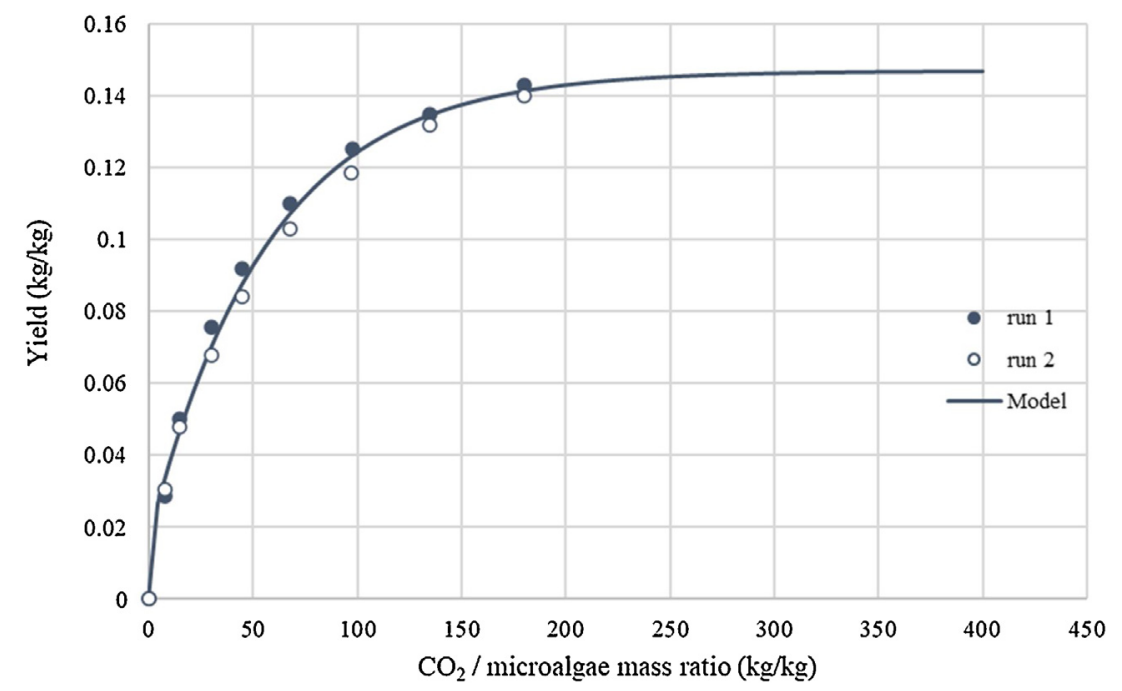

Fig. 3. $\mathrm{SC}-\mathrm{CO}_{2}$ extraction curves, repeatability test on AFD N. maritima at 300 bar and $333 \mathrm{~K}$.

Table 3

Regression coefficients of the polynomial RSM equation and analysis of variance for neutral lipids yield, Chl a and total carotenoids concentration.

\begin{tabular}{|c|c|c|c|c|c|c|}
\hline \multirow[b]{2}{*}{ Coefficient (factor) } & \multicolumn{2}{|c|}{ Neutral lipids yield (\%) } & \multicolumn{2}{|l|}{ Chl a $(\mu \mathrm{g} / \mathrm{g})$} & \multicolumn{2}{|c|}{ Total carotenoids $(\mu \mathrm{g} / \mathrm{g})$} \\
\hline & Coefficients values & p-value (\%) & Coefficients values & p-value (\%) & Coefficients values & p-value (\%) \\
\hline $\mathrm{b}_{0}$ & 11.41 & - & 0.321 & - & 0.35 & - \\
\hline$b_{1}(P)$ & 2.465 & $0.72^{*}$ & 0.362 & 9.2 & 0.302 & $2.18^{\mathrm{a}}$ \\
\hline$b_{2}(\mathrm{~T})$ & 1.562 & $2.53^{\mathrm{a}}$ & 0.005 & 97.5 & 0.055 & 48.1 \\
\hline $\mathrm{b}_{11}(\mathrm{PP})$ & -1.87 & 6.4 & 0.288 & 34.3 & 0.105 & 44.2 \\
\hline $\mathrm{b}_{22}(\mathrm{TT})$ & 0.052 & 94.1 & -0.312 & 31.2 & -0.165 & 25.9 \\
\hline $\mathrm{b}_{12}(\mathrm{PT})$ & 1.055 & 10.6 & 0.007 & 97 & 0.083 & 39.9 \\
\hline $\mathrm{R}^{2}$ & 0.96 & - & 0.74 & - & 0.89 & - \\
\hline
\end{tabular}

a Significant factor.

Regardless of temperature and drying process, at 100 bar the recovery of $\mathrm{Chl}$ a and total carotenoids in the extracts was very low (between zero and $0.07 \mu \mathrm{g} / \mathrm{g}$ ). This result was expected as carotenoids have low solubility in SC- $\mathrm{CO}_{2}$ at these experimental conditions [33]. A similar result was obtained by Macias Sanchez et al. [16].

Pressure and temperature were reported to significantly influence the amount of extracted neutral lipids (Table 3 and Fig. 4 (a)). Nevertheless, pressure had a more significant effect than temperature. Indeed, increasing the pressure at a set temperature significantly increased the amount of extracted neutral lipids. Increasing both pressure and temperature led to an increase of the extracted amount of neutral lipids. This is due to a higher solubility of the extracted compounds in the $\mathrm{SC}-\mathrm{CO}_{2}$. The highest neutral lipids yield (14.5\%) was found at 300 bar and $333 \mathrm{~K}$. The retrograde solubility behavior was not observed at these operating conditions.

In the experimental regime below 200 bar, no significant effects of pressure and temperature were found for the recovery of Chl a while pressure was found to be a significant factor for the recovery of total carotenoids (Table 3). Above 200 bar, increasing pressure at a given temperature increases extract concentration of both pigments. A similar tendency was reported by Macias-Sanchez et al. [16] on $N$. gaditana. The optimal experimental operating condi- 


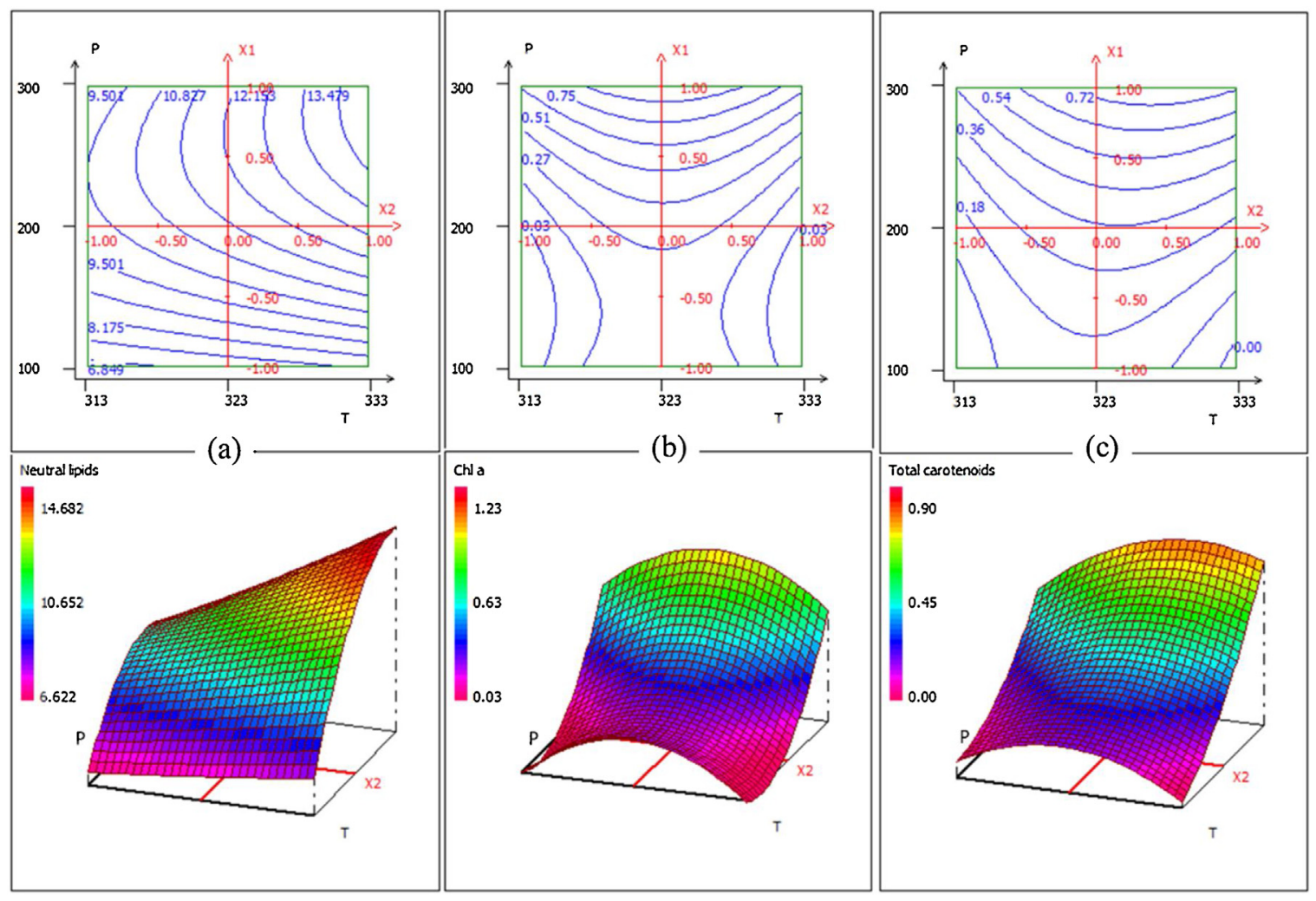

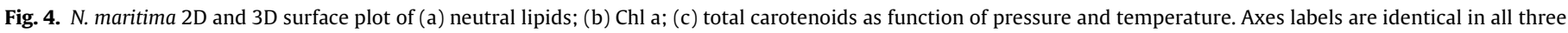
plots.

tions for the recovery of pigments from AFD $N$. maritima were found to be at $300 \mathrm{bar}$ and $323 \mathrm{~K}(1.39 \mu \mathrm{g} / \mathrm{g}$ and $0.95 \mu \mathrm{g} / \mathrm{g}$ for Chl a and carotenoids respectively). Macias-Sanchez et al. reported, at 300 bar, a better recovery of pigments at $333 \mathrm{~K}$. The difference may be due to drying method leading to different final cell structures.

Macias-Sanchez et al. [16] reported that the highest amount of $\mathrm{Chl}$ a and carotenoids were recovered at 400 bar and $333 \mathrm{~K}$. An extraction experiment was carried out at these experimental conditions with a $\mathrm{CO} 2$ flow rate of $0.15 \mathrm{~kg} / \mathrm{h}$. At a $\mathrm{CO}_{2} /$ microalgae mass ratio of $180 \mathrm{~kg} / \mathrm{kg}$, the neutral lipids yield was about $15.5 \mathrm{wt} \%$ and the concentration of $\mathrm{Chl} \mathrm{a}$ and total carotenoids were 1.07 and $0.83 \mu \mathrm{g} / \mathrm{g}$ respectively. At $333 \mathrm{~K}$, increasing the pressure led to increasing the recovery of neutral lipids and the concentration of pigments in the extracts. In this study, the best operating conditions for the extraction of both $\mathrm{Chl}$ a and total carotenoids were 300 bar and $323 \mathrm{~K}$ at a $\mathrm{CO}_{2}$ flow rate of $0.15 \mathrm{~kg} / \mathrm{h}$.

Considering the results reported in this study and by MaciasSanchez et al. [16], when pigments are targeted, pressures lower than 200 bar should be avoided due to the low solubility of pigments in $\mathrm{SC}-\mathrm{CO}_{2}$.

\section{Neutral lipids composition}

Lipid analyses to determine FFA and TAG contents (lipid classes) were performed on the $\mathrm{SC}-\mathrm{CO}_{2}$ extracts for pressures ranging from 100 to 300 bar and temperatures ranging from 313 to $333 \mathrm{~K}$. Extracts were esterified and the fatty acid methyl esters (FAMEs) were identified (Analyses could not be performed for the experiments conducted at 100 bar, 323 and $333 \mathrm{~K}$ due to a low amount of collected oil (extracts were primarily composed of volatile compounds).

Table 4). TAG and FFA amounts are described as the mass of the constituents relative to the extract mass (wt\%). Analyses could not
Table 4

Neutral lipid content in extracted oil from N. maritima.

\begin{tabular}{lllll}
\hline Experiment & FFA (wt\%) & TAG (wt\%) & TAG +FFA (wt\%) & C20:5 (wt\%) \\
\hline 100 bar, 313 K & 39.8 & 5.1 & 44.9 & 7.1 \\
200 bar, 313 K & 28.7 & 31.6 & 60.3 & 8.3 \\
200 bar, 323 K & 30.7 & 28.1 & 58.8 & 7.7 \\
200 bar, 333 K & 28.9 & 31.9 & 60.8 & 7.9 \\
300 bar, 313K & 32.1 & 21.3 & 53.4 & 8.5 \\
300 bar, 323 K & 20 & 36.1 & 56.1 & 8.3 \\
300 bar, 333 K & 27.6 & 33.9 & 61.5 & 7.5 \\
\hline
\end{tabular}

a Total lipids.

be performed for the experiments conducted at 100 bar, 323 and $333 \mathrm{~K}$ due to a low amount of collected oil (extracts were primarily composed of volatile compounds).

A non-negligible amount of EPA (C20:5), a high added value $\omega-3$ acid was found. The amount of EPA varied between 7.1 and $8.5 \mathrm{wt} \%$. An amount of the same order of magnitude ( $8.06 \mathrm{wt} \%$ ) was reported by Millao et al. [18] at 593 bar and $337 \mathrm{~K}$ on FD N. gaditana.

Other FAMEs including C15:0, C16:1, C18:0, C18:1, C18:2, C20:0 and C20:4, were found to be at constant value respectively $0.4 \%$, $20 \%, 1.5 \%, 0.5 \%, 1.3 \%, 0.3 \%$ and $2.6 \%$ regardless of the extraction conditions. Palmitoleic acid (C16:1) was found to be the main extracted FAME from N.maritima. Similar results were reported in the literature $[4,15,19,20]$. Based on these studies it is well-known that the amount of extracted FAMEs should be the same when Soxhlet extraction is performed.

The overall results reported in Table 4 suggest a degradation of TAG to FFA, a similar observation was reported by Crampon et al. [11] and Mouahid et al. [17]. This degradation was perhaps due to the remaining water content after the AFD process. The main issue is that a higher drying period would lead to a degradation of valuable compounds [10]. The highest amount of TAG + FFA (61.5 wt\%) 
was found to be recovered at 300 bar and $333 \mathrm{~K}$ and the lowest (44.9 wt\%DM) at 100 bar and $313 \mathrm{~K}$.

\section{Effect of drying mode on $\mathrm{SC}-\mathrm{CO}_{2}$ extraction kinetics}

The effect of the drying mode on the $\mathrm{SC}-\mathrm{CO}_{2}$ extraction kinetics from $N$. maritima was studied at 100 bar and $313 \mathrm{~K}$. The extraction curves are reported in Fig. 5 and clearly show a higher extraction kinetic when $N$. maritima is AFD.

The mass losses from AFD biomass averaged about 55\% higher than those from RD biomass. In an effort to understand how the drying mode affected the structure of the microalgae, RD and AFD N. maritima were evaluated by SEM Fig. 6). SEM images suggest that $\mathrm{RD}$ produced fewer fine cracks in the particulates' surface than AFD. The thick cell wall structure of Nannochloropsis sp. is known to be difficult to disrupt for extraction of intracellular products [34,35]. It seems that the high temperature and short residence time of RD (about $353 \mathrm{~K}$; less than $30 \mathrm{~s}$ ) did not cause sufficient alteration of cell walls of the biomass. Considering that the initial extraction curve is related to solubility, it appears that when RD was applied, a less solute was accessible to $\mathrm{SC}-\mathrm{CO}_{2}$. Additionally, the $\mathrm{SC}-\mathrm{CO}_{2}$ extracted solute composition varied depending on the drying mode. Quantities of FFA and TAG in wet $N$. maritima paste, in RD biomass (pre-extraction), and AFD biomass (pre-extraction) were determined. The TAG /(TAG + FFA) ratios were about $83 \%, 85 \%$, and $65 \%$ for the algal paste, RD biomass, and AFD biomass, respectively.

This suggests that the amounts of TAG and FFA were not significantly modified during RD compared to AFD where higher water content $(\sim 13 \mathrm{wt} \%$ ) and longer processing time were associated with degradation of TAG to FFA by hydrolysis. A similar effect due to water was observed by Elst et al. [25]. Depending on the drying mode, the cell walls of microalgae were impacted in different ways inducing a different accessible solute composition to $\mathrm{SC}-\mathrm{CO}_{2}$. It seems that cells are more intact when $\mathrm{RD}$ is applied compared to AFD. In addition, the intensity and duration of AFD appears to have caused a degradation of glycerides to FFA and modify the initial solute composition as shown in other studies [10,11]. The extraction kinetics were lower when RD was performed but, the extracted oil quality is better in comparison with extracted oil from AFD biomass. Since glycerides were the solute of interest in this study, RD seems to be more appropriate than AFD.

\section{Experiments performed on $R D N$ N. Salina}

Considering that RD did not lead to a degradation of microalgae compounds (section 4.1.3), it was chosen to perform $\mathrm{SC}-\mathrm{CO}_{2}$ extraction on $\mathrm{RD} N$. salina. The $\mathrm{SC}-\mathrm{CO}_{2}$ extraction experiments were performed at 300 and 400 bar, at a temperature of $333 \mathrm{~K}$, and a $\mathrm{CO}_{2}$ flow rate of $0.15 \mathrm{~kg} / \mathrm{h}$. The effects of co-solvent and high-water content were studied.

Extraction of valuable compounds from $N$. Salina with pure $\mathrm{SC}-\mathrm{CO}_{2}$

The $\mathrm{SC}-\mathrm{CO}_{2}$ extraction curves obtained from $N$. salina are presented in Fig. 7. Two set of experiments were performed for each operating condition to check the repeatability. The average deviations between the two sets of experiments were comprised between $2.2 \%$ and $3.9 \%$ which is very satisfactory. In Fig. 7, the shapes of the modelled $\mathrm{SC}-\mathrm{CO}_{2}$ extraction curves indicate that the extraction was near completion at a $\mathrm{CO}_{2} /$ microalgae mass ratio of $180 \mathrm{~kg} / \mathrm{kg}$ (yield of $23 \%$ at 300 bar and $24 \%$ at 400 bar). Considering that only neutral lipids are extracted by $\mathrm{SC}-\mathrm{CO}_{2}$ and the extraction is almost complete, it can be considered that the strain of $N$. salina presented in this study contains about $24 \mathrm{wt} \%$ of neutral lipids.

Pigment analysis (Chl a and carotenoids) are reported in Table 5. The total carotenoids concentration was consistently higher than $\mathrm{Chl}$ a concentration. Increasing the pressure from 300 to $400 \mathrm{bar}$
Table 5

$\mathrm{Chl}$ a and total carotenoids concentration in $\mathrm{N}$. salina extracts for a $\mathrm{CO}_{2} /$ dry microalgae mass ratio of $180 \mathrm{~kg} / \mathrm{kg}$.

\begin{tabular}{lll}
\hline & Concentration $(\mu \mathrm{g} / \mathrm{g})$ & \\
\hline Experiment & Chl a & Total carotenoids \\
300 bar & 0.11 & 0.58 \\
300 bar ethanol impregnation & 0.34 & 0.66 \\
400 bar & 0.12 & 0.78 \\
400 bar -23.9 wt\% water & 0.27 & 0.49 \\
\hline
\end{tabular}

induced an increase in the total carotenoids' concentration in the $\mathrm{SC}-\mathrm{CO}_{2}$ extracts (about 29\%), while the concentration of Chl a was more or less the same. Increasing the pressure seems to have the effect only on the recovery of total carotenoids. The observations were slightly different that those reported by Macias-Sanchez et al. [16] who reported an increase of both Chl a and total carotenoids from FD Nannochloropsis gaditana. This difference can be explained by an accessible solute of different composition caused by the drying mode.

\section{Extraction of valuable compounds from N. Salina with ethanol as co-solvent}

Two experiments were performed at 300 bar and $333 \mathrm{~K}$ with ethanol as co-solvent. In the first extraction, the biomass was impregnated with ethanol (ethanol:biomass $=2: 5 \mathrm{wt} / \mathrm{wt}$ ). Then the system was kept in a closed vessel under controlled humidity to allow the maceration of the biomass in ethanol for a duration of about $24 \mathrm{~h}$. The second experiment was performed using a mixture of $\mathrm{SC}-\mathrm{CO}_{2}$ with ethanol as co-solvent. The mass ratio $\mathrm{CO}_{2} /$ ethanol was $4.3 \%(\mathrm{wt} / \mathrm{wt})$. Difference in color between the extracts recovered at 300 bar and $333 \mathrm{~K}$ with and without co-solvent has been observed. The different colored extracts, orange without any co-solvent, maroon for maceration and green for $\mathrm{SC}-\mathrm{CO}_{2}$ ethanol with ethanol as co-solvent, indicate that they did not have the same composition.

SEM was performed on RD N. salina (Fig. 8) for the extraction conditions studied. The effect of the maceration process on cell disruption is shown by comparing Fig. 8 (a) and (c). It can be seen that the particulate structure of the biomass was significantly disrupted and mainly allowed the extraction of both $\mathrm{Chl}$ a and carotenoids (Table 5). Using an ethanol co-solvent increased the recovery of both $\mathrm{Chl}$ a and total carotenoids by 67.6 and $12 \%$ respectively compared to pure SC- $\mathrm{CO}_{2}$ (Fig. 8 (b) and (d)). The extract color indicates that the particulate structure of the biomass was disrupted more intensively after co-solvent extraction and allowed increased extraction of Chl a.

\section{Effects of high-water content}

A SC $-\mathrm{CO}_{2}$ extraction experiment was performed at 400 bar and $333 \mathrm{~K}$ on a sample containing a water content of $23.9 \mathrm{wt} \%$. The results obtained were compared to those obtained with extraction experiment performed with sample of water content of about $3.4 \mathrm{wt} \%$. The extraction kinetics were reported in Fig. 9.

In previous works $[10,11]$ when Dunaliella salina paste biomass was submitted to different degrees of air flow drying (water content from 5 to $23 \mathrm{wt} \%$ ) [10] and when AFD N. oculata biomass contained moisture up to $20 \mathrm{wt} \%$ [11], an increase of the global extraction kinetics was reported. Water was not reported to act as barrier for diffusion for $N$. oculata and was reported to act as cosolvent for the extraction of pigments from Dunaliella salina. In the present study, the extraction kinetics are higher with lower water content. When extraction was performed on biomass with water content of $23.9 \mathrm{wt} \%$, the shape of the extraction curve differed from that usually obtained (Figure 9 ). The analysis of the extract shows that when water was added, the concentration of $\mathrm{Chl}$ a was approximately two times higher than RD N. salina while the concentration of total 


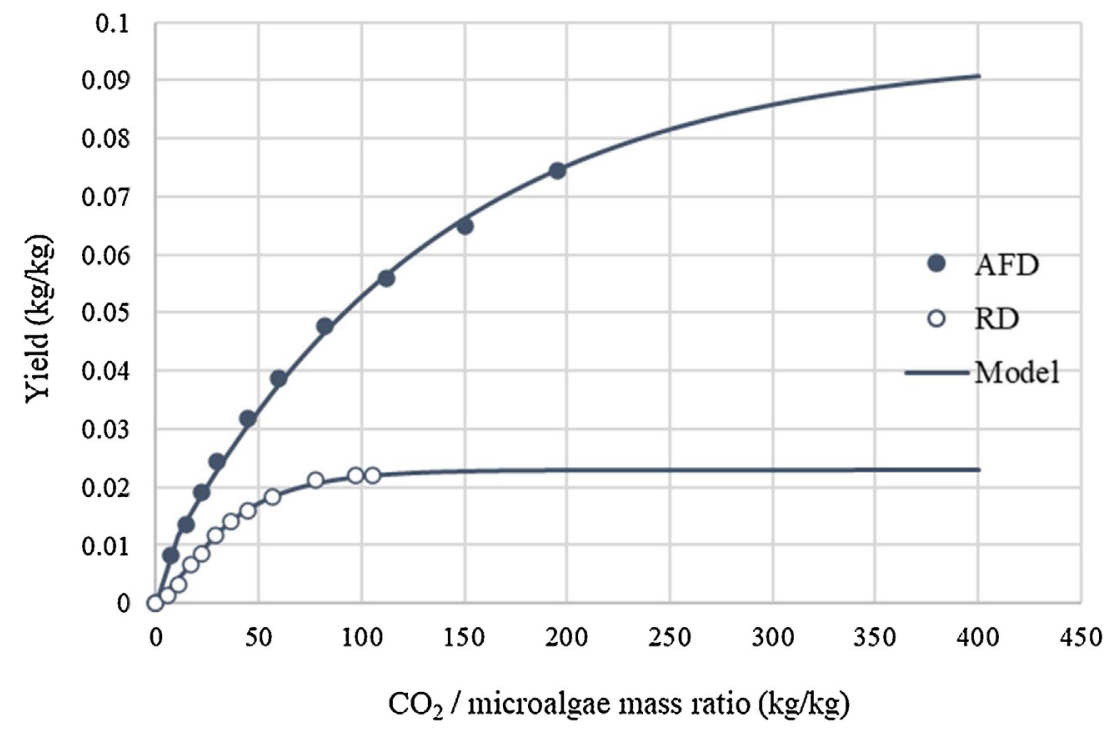

Fig. 5. Effects of drying mode on extraction kinetics at $100 \mathrm{bar}, 313 \mathrm{~K}$ and $0.15 \mathrm{~kg} / \mathrm{h}$.
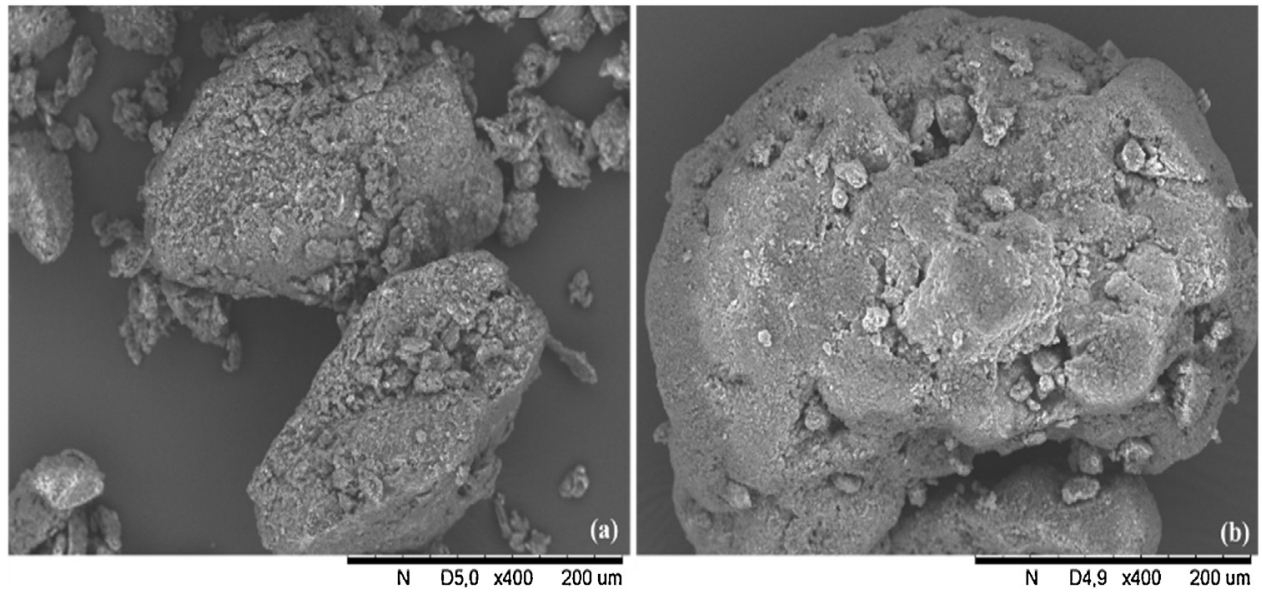

Fig. 6. Pre-extraction SEM images of $N$. maritima (a) AFD biomass; (b) RD biomass.

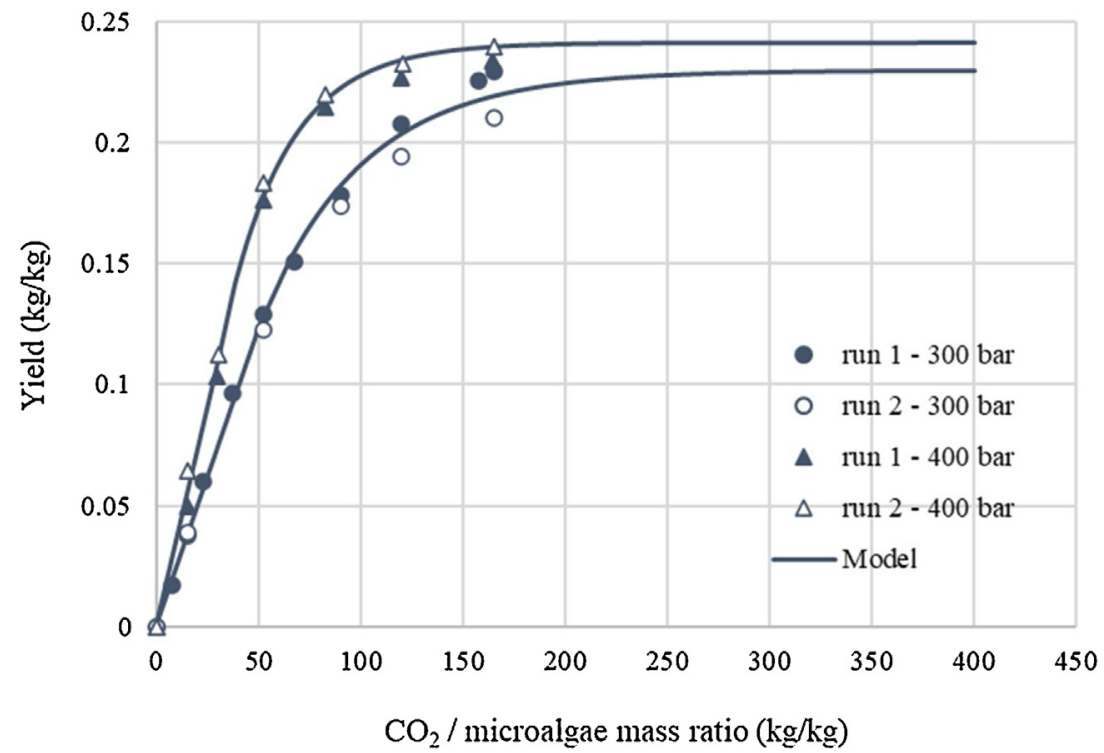

Fig. 7. Repeatability on RD N. salina at 333 K, 300 bar and.400 bar. 

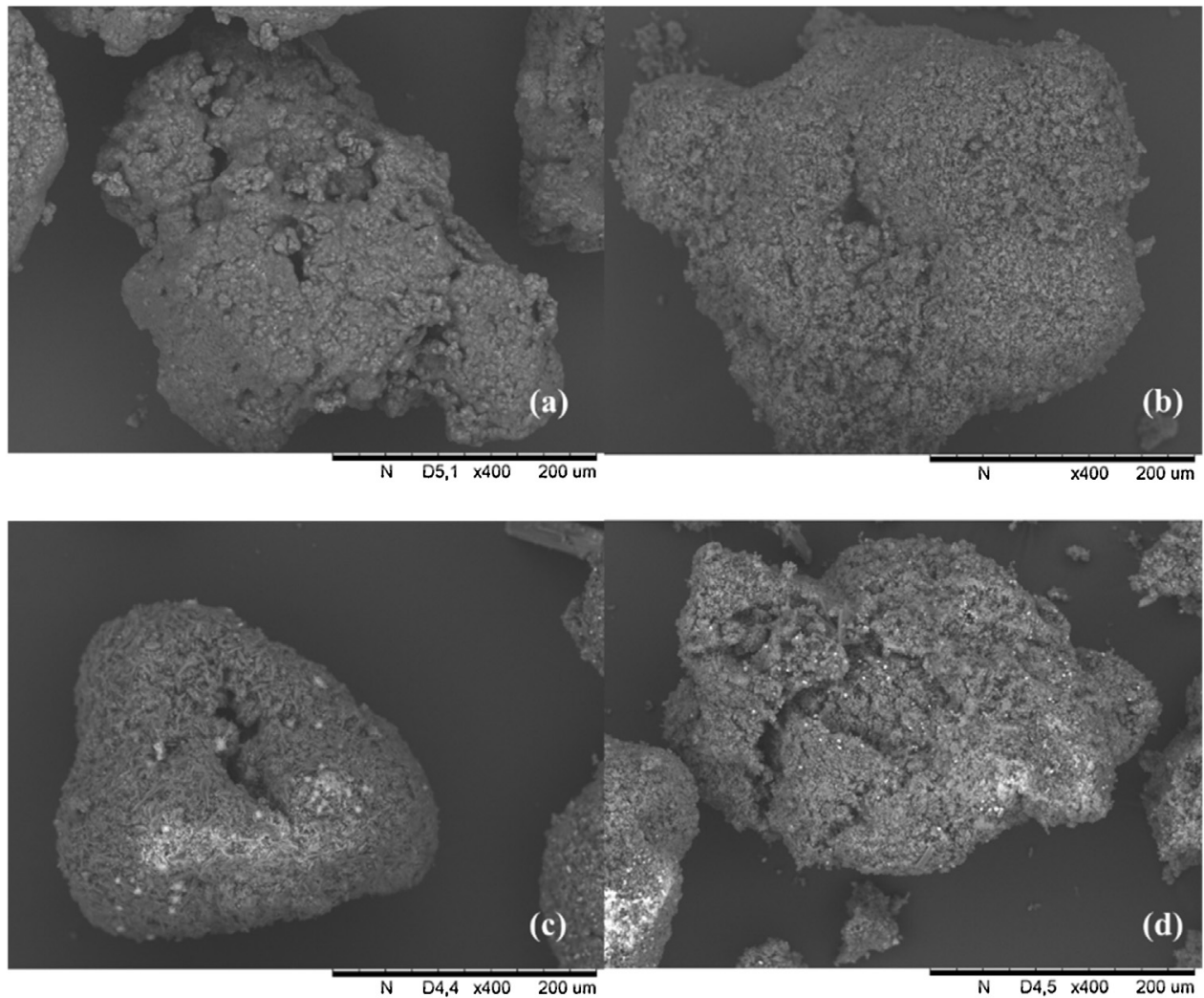

Fig. 8. SEM images of RD N.salina (a) before $\mathrm{SC}-\mathrm{CO}_{2}$ extraction, (b) after pure $\mathrm{SC}-\mathrm{CO}_{2}$ extraction, (c) after co-solvent extraction, (d) after maceration in ethanol.

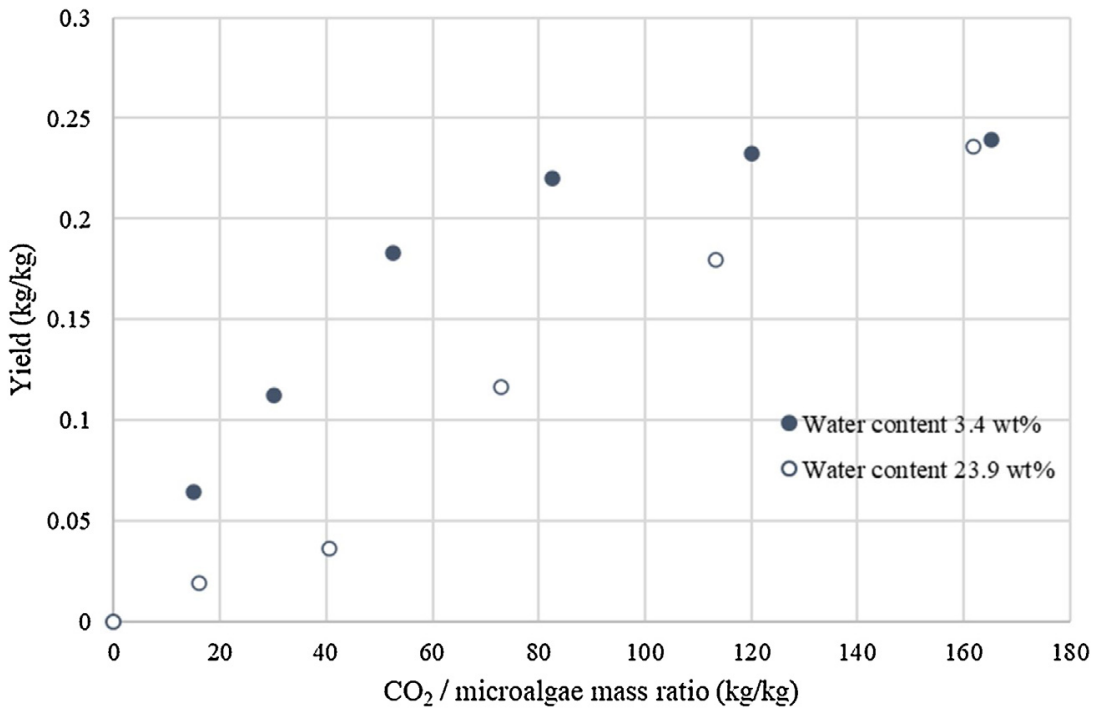

Fig. 9. Effects of water content at 400 bar and $333 \mathrm{~K}$ on RD N. salina.

carotenoids was $42 \%$ lower (Table 5 ) indicating that water may act as co-solvent for Chl a. Depending on the drying method, the cell structure of the dried biomass is different. RD likely causes the difference in the interaction between water and $N$. salina biomass structure versus the results reported by Crampon et al on $N$. oculata [11]. When water was added to the RD biomass, a water layer may have been formed acting as a barrier to the diffusion of $\mathrm{SC}-\mathrm{CO}_{2}$. During the extraction process, this additional water was evacuated with $\mathrm{CO}_{2}$ flow - leaving no water in either the extracts or the residues. This was demonstrated by characterizing the water content in the algal residue after extraction. As water has very low solubility in $\mathrm{SC}-\mathrm{CO}_{2}$ [36], it can be assumed that at a set extraction period, the amount of water on the biomass was low enough to be solubilized by $\mathrm{SC}-\mathrm{CO}_{2}$ and to act as co-solvent for the recovery of Chl a.

\section{Modelling discussions}

The calculated model parameters for $N$. maritima and $N$. salina were reported in Table 6. As discussed in section 4.1.3, the drying mode impacts the microalgae cell walls in different ways inducing a different composition and amount of accessible free solutes 
Table 6

Sovová's mathematical model parameters for N. maritima and N. salina.

\begin{tabular}{|c|c|c|c|c|c|c|c|c|c|}
\hline Strain & Operating conditions & $\mathrm{y}_{\mathrm{s}} \times 10^{3}$ & $\mathrm{C}_{\mathrm{u}}$ & $\mathrm{C}_{1}$ & $\mathrm{C}_{2}$ & $\mathrm{k}_{\mathrm{s}} \mathrm{a}_{\mathrm{s}} \times 10^{5}$ & r & $\mathrm{q}_{1}$ & AARD \\
\hline \multirow{3}{*}{ N. maritima } & 300 bar - $333 \mathrm{~K}$ (AFD) & 5.920 & 0.147 & 0.886 & 0.0149 & 7.695 & 0.148 & 5.265 & 2.80 \\
\hline & 100 bar - $313 \mathrm{~K}$ (AFD) & 1.093 & 0.095 & 0.951 & 0.0069 & 3.651 & 0.075 & 8.287 & 2.31 \\
\hline & 100 bar - $313 \mathrm{~K}(\mathrm{RD})$ & 0.400 & 0.023 & 1.248 & 0.0316 & 12.921 & 0.047 & 17.057 & 9.50 \\
\hline \multirow{2}{*}{ N. salina } & 300 bar - $333 \mathrm{~K}(\mathrm{RD})$ & 2.461 & 0.230 & 1.269 & 0.015 & 8.833 & 0.251 & 68.134 & 1.33 \\
\hline & 400 bar - $333 \mathrm{~K}(\mathrm{RD})$ & 3.600 & 0.241 & 1.455 & 0.025 & 17.072 & 0.107 & 39.498 & 1.62 \\
\hline
\end{tabular}

to $\mathrm{SC}-\mathrm{CO}_{2}$. The amount and the mixture composition are then different when RD and AFD are applied. At 100 bar and $313 \mathrm{~K}$, the comparison between the two drying modes showed that the extracted mixture had a higher solubility in $\mathrm{SC}-\mathrm{CO}_{2}$ when AFD was applied.

When RD was applied the representative part of the solubility mixture on the extraction curve is longer according to the estimated values of $\mathrm{q}_{1}$ which delay the appearance of the second part of the extraction curve (diffusion part). Since the solid particles of dried and grinded samples have similar size and shapes, the values of $\mathrm{k}_{\mathrm{s}} \mathrm{a}_{\mathrm{s}}$ parameter can be assimilated to the values of the mass transfer coefficient between the broken cell and the solvent $\mathrm{k}_{\mathrm{s}}$.

The extractions performed on $N$. maritima showed that the mass transfer coefficient is higher when RD was applied due to a longer period for solubility mixture in $\mathrm{SC}-\mathrm{CO}_{2}$ (high value of $\mathrm{q}_{1}$ ). Considering that solutes compositions are different according to drying mode, it is difficult to give an accurate conclusion. Nevertheless, a general tendency can be identified. Compared to AFD, when RD was applied it can be assumed that the part of its easily accessible solute to $\mathrm{SC}-\mathrm{CO}_{2}$ is high. When this solute mixture is extracted, the transfer between the broken cells and the solvent is faster (higher value of $k_{s} a_{s}$ ). Hence, the choice of drying mode may depend on the targeted compounds in the solute composition. The focus on the extraction kinetics can lead to unwanted compounds and/or to a degradation of the extracted compounds.

The calculated parameters (Table 6) are of the same order of magnitude than those reported by Mouahid et al. on N. oculata [17] and Dunaliella salina [10]. In the first study, the authors assumes that the extracted solute was the same for both AFD and FD while in the second study that FD induce high transfer limitation due to diffusion (extraction of type D) due to the shape of the curves. The reported experimental tendencies were the same than the one observed in this work: a higher extraction kinetics when AFD was performed with a shorter solubility period. The total amount of accessible solutes is lower when RD or FD is performed, nevertheless, transfer parameters (according to Sovová's mathematical model) are good and no degradation of the extracted compounds was observed. It is worth noting that the additional information reported in the work give a new perspective:

- the choice of extraction type according to the shape of the extraction curve as first approximation is a correct approach, nevertheless in some specific cases it can lead to mistakes. It is then advised to perform additional analysis like solubility estimation and/or extracted solute analysis.

- The drying method should be chosen according to targeted compounds and not according to the highest extraction kinetics. RD and FD seem to be more appropriate to avoid.

\section{Conclusion}

Supercritical $\mathrm{CO}_{2}$ extractions were performed on $N$. maritima and $N$. salina provided by Cellana LLC. The effects of drying pretreatment and co-solvent on extraction efficiency were presented. No degradation of TAG to FFA was observe when RD was applied contrary to AFD where lipid degradation was observed. When pure
$\mathrm{SC}-\mathrm{CO}_{2}$ extraction was applied at 300 bar and $323 \mathrm{~K}$ it was possible to extract high amount of $\mathrm{Chl}$ a and total carotenoids. The amount of C16:1 and EPA remain constant with varying extraction conditions. Maceration in ethanol enhanced the extraction of total carotenoids by disrupting the surface of the algae particles before extraction. It is worth noting that the water-content of $23.9 \mathrm{wt} \%$ in the biomass leads to strong diffusion but had a co-solvent effect when extracting $\mathrm{Chl}$ a, but ultimately resulted in a lower recovery of total carotenoids. Depending on the drying process, the $\mathrm{SC}-\mathrm{CO}_{2}$ extracted solute mixture has a different composition leading to different extraction kinetics. This may be due to the drying time duration and intensity which can lead to a degradation of compounds and/or to non-significant alteration of the biomass cell walls. The first part of the extraction curve is related to solute solubility whatever the drying mode. Hence, the extraction type was of type A according to Sovová's mathematical model for all extraction curves.

\section{Author Contribution}

The manuscript was written through contributions of all authors. All authors have given approval to the final version of the manuscript. These authors contributed equally.

\section{Declaration of Competing Interest}

We declare that we do not have any conflicts of interest to declare.

\section{Acknowledgment}

This work was conducted with financial support from Cellana LLC (Hawaii, USA).

\section{References}

[1] Z. Xue, F. Wan, W. Yu, J. Liu, Z. Zhang, X. Kou, Edible oil production from microalgae: a review, Eur. J. Lipid Sci. Technol. 120 (2018), 1700428, http://dx. doi.org/10.1002/ejlt.201700428.

[2] C. Crampon, O. Boutin, E. Badens, Supercritical carbon dioxide extraction of molecules of interest from microalgae and seaweeds, Ind. Eng. Chem. Res. 50 (2011) 8941-8953, http://dx.doi.org/10.1021/ie102297d.

[3] E.T. Chua, P.M. Schenk, A biorefinery for Nannochloropsis: induction, harvesting, and extraction of EPA-rich oil and high-value protein, Bioresour. Technol. 244 (2017) 1416-1424, http://dx.doi.org/10.1016/j.biortech.2017.05 124.

[4] B.P. Nobre, F. Villalobos, B.E. Barragán, A.C. Oliveira, A.P. Batista, P.A.S.S. Marques, R.L. Mendes, H. Sovová, A.F. Palavra, L. Gouveia, A biorefinery from Nannochloropsis sp. Microalga - extraction of oils and pigments. Production of biohydrogen from the leftover biomass, Bioresource Technol. 135 (2013) 128-136, http://dx.doi.org/10.1016/j.biortech.2012.11.084.

[5] L.M. Lubián, O. Montero, I. Moreno-Garrido, E. Huertas, C. Sobrino, M.G. Valle, G. Parés, Nannochloropsis (Eustigmatophyceae) as source of commercially valuable pigments, (n.d.) 7.

[6] F.X. Malcata, Microalgae and biofuels: A. Promising partnership? Trends Biotechnol. 29 (2011) 542-549, http://dx.doi.org/10.1016/j.tibtech.2011.05. 005.

[7] A. Molino, S. Mehariya, G. Di Sanzo, V. Larocca, M. Martino, G.P. Leone, T. Marino, S. Chianese, R. Balducchi, D. Musmarra, Recent developments in supercritical fluid extraction of bioactive compounds from microalgae: Role of key parameters, technological achievements and challenges, J. Co2 Util. 36 (2020) 196-209, http://dx.doi.org/10.1016/j.jcou.2019.11.014. 
[8] R. Gallego, L. Montero, A. Cifuentes, E. Ibáñez, M. Herrero, Green extraction of bioactive compounds from microalgae, J. Anal. Test. (2018), http://dx.doi.org/ 10.1007/s41664-018-0061-9.

[9] C. Crampon, C. Nikitine, M. Zaier, O. Lépine, C.D. Tanzi, M.A. Vian, F. Chemat, E. Badens, Oil extraction from enriched Spirulina platensis microalgae using supercritical carbon dioxide, J. Supercrit. Fluids 119 (2017) 289-296, http:// dx.doi.org/10.1016/j.supflu.2016.10.006.

[10] A. Mouahid, C. Crampon, S.-A.A. Toudji, E. Badens, Effects of high water content and drying pre-treatment on supercritical CO2 extraction from Dunaliella salina microalgae: experiments and modelling, J. Supercrit. Fluids 116 (2016) 271-280, http://dx.doi.org/10.1016/j.supflu.2016.06.007.

[11] C. Crampon, A. Mouahid, S.-A.A. Toudji, O. Lépine, E. Badens, Influence of pretreatment on supercritical CO2 extraction from Nannochloropsis oculata, J. Supercrit. Fluids 79 (2013) 337-344, http://dx.doi.org/10.1016/j.supflu.2012. 12.022.

[12] D.F. Tirado, L. Calvo, The Hansen theory to choose the best cosolvent for supercritical CO2 extraction of $\beta$-carotene from Dunaliella salina, J. Supercrit. Fluids 145 (2019) 211-218, http://dx.doi.org/10.1016/j.supflu.2018.12.013.

[13] E. Günerken, E. D’Hondt, M.H.M. Eppink, L. Garcia-Gonzalez, K. Elst, R.H. Wijffels, Cell disruption for microalgae biorefineries, Biotechnol. Adv. 33 (2015) 243-260, http://dx.doi.org/10.1016/j.biotechadv.2015.01.008.

[14] E. D'Hondt, J. Martín-Juárez, S. Bolado, J. Kasperoviciene, J. Koreiviene, S. Sulcius, K. Elst, L. Bastiaens, Cell disruption technologies, in: Microalgae-Based Biofuels and Bioproducts, Elsevier, 2017, pp. 133-154, http://dx.doi.org/10.1016/B978-0-08-101023-5.00006-6.

[15] G. Andrich, U. Nesti, F. Venturi, A. Zinnai, R. Fiorentini, Supercritical fluid extraction of bioactive lipids from the microalgaNannochloropsissp, Eur. J. Lipid Sci. Technol. 107 (2005) 381-386, http://dx.doi.org/10.1002/ejlt. 200501130.

[16] M.D. Macías-Sánchez, C. Mantell, M. Rodríguez, E. Martínez de la Ossa, L.M. Lubián, O. Montero, Supercritical fluid extraction of carotenoids and chlorophyll $a$ from Nannochloropsis gaditana, J. Food Eng. 66 (2005) 245-251, http://dx.doi.org/10.1016/j.jfoodeng.2004.03.021.

[17] A. Mouahid, C. Crampon, S.-A.A. Toudji, E. Badens, Supercritical CO2 extraction of neutral lipids from microalgae: experiments and modelling, J. Supercrit. Fluids 77 (2013) 7-16, http://dx.doi.org/10.1016/j.supflu.2013.01.024.

[18] S. Millao, E. Uquiche, Antioxidant activity of supercritical extracts from Nannochloropsis gaditana: correlation with its content of carotenoids and tocopherols, J. Supercrit. Fluids 111 (2016) 143-150, http://dx.doi.org/10. 1016/j.supflu.2016.02.002.

[19] A.M. Aliev, I.M. Abdulagatov, The study of microalgae Nannochloropsis salina fatty acid composition of the extracts using different techniques. SCF vs conventional extraction, J. Mol. Liquids. 239 (2017) 96-100, http://dx.doi.org/ 10.1016/j.molliq.2016.08.021.

[20] R. Feller, Â.P. Matos, S. Mazzutti, E.H.S. Moecke, M.V. Tres, R.B. Derner, J.V. Oliveira, A.F. Junior, Polyunsaturated $\omega-3$ and $\omega-6$ fatty acids, total carotenoids and antioxidant activity of three marine microalgae extracts obtained by supercritical CO2 and subcritical n-butane, J. Supercrit. Fluids 133 (2018) 437-443, http://dx.doi.org/10.1016/j.supflu.2017.11.015.

[21] S. Obeid, N. Beaufils, S. Camy, H. Takache, A. Ismail, P.-Y. Pontalier, Supercritical carbon dioxide extraction and fractionation of lipids from freeze-dried microalgae Nannochloropsis oculata and Chlorella vulgaris, Algal Res. 34 (2018) 49-56, http://dx.doi.org/10.1016/j.algal.2018.07.003.

[22] M.D. Macías-Sánchez, C. Mantell Serrano, M. Rodríguez Rodríguez, E. Martínez de la Ossa, L.M. Lubián, O. Montero, Extraction of carotenoids and chlorophyll from microalgae with supercritical carbon dioxide and ethanol as cosolvent, J. Sep. Sci. 31 (2008) 1352-1362, http://dx.doi.org/10.1002/jssc.200700503.

[23] M. Solana, C.S. Rizza, A. Bertucco, Exploiting microalgae as a source of essential fatty acids by supercritical fluid extraction of lipids: Comparison between Scenedesmus obliquus, Chlorella protothecoides and Nannochloropsis salina, J. Supercrit. Fluids 92 (2014) 311-318, http://dx.doi. org/10.1016/j.supflu.2014.06.013.

[24] P.D. Patil, K.P.R. Dandamudi, J. Wang, Q. Deng, S. Deng, Extraction of bio-oils from algae with supercritical carbon dioxide and co-solvents, J. Supercrit. Fluids 135 (2018) 60-68, http://dx.doi.org/10.1016/j.supflu.2017.12.019.

[25] K. Elst, M. Maesen, G. Jacobs, L. Bastiaens, S. Voorspoels, K. Servaes, Supercritical CO2 extraction of nannochloropsis sp.: a lipidomic study on the influence of pretreatment on yield and composition, Molecules 23 (2018) 1854, http://dx.doi.org/10.3390/molecules23081854.

[26] S.M. Walas, Chemical Process Equipment: Selection and Design, Third Edition, BH, Butterworth-Heinemann, an imprint of Elsevier, Amsterdam, 2012.

[27] Daniel Frosterud, Michael Wahlberg, Jakob Sloth, Michel Themes, Selected Drying Technologies and Particle Engineering for the Future Biorefinery, Stockholm, 2011 http://www.christianberner.se/\$-1/file/filarkiv/cbab/ pulverteknik-1/drying-technologies-for-the-future-biorefinery.pdf.

[28] S. Moran, Process Plant Layout, Second Edition, Butterworth-Heinemann is an imprint of Elsevier, Kidlington, Oxford, United Kingdom; Cambridge, MA United States, 2017.

[29] H.K. Lichtenthaler, C. Buschmann, Chlorophylls and Carotenoids: Measurement and Characterization by UV-VIS Spectroscopy, Current Protocols in Food Analytical Chemistry, 2001, http://dx.doi.org/10.1002/ 0471142913.faf0403s01/full (accessed October 18, 2016).

[30] H.K. Lichtenthaler, C. Buschmann, Chlorophylls and carotenoids: measurement and characterization by UV-VIS spectroscopy, Current Protocols in Food Anal. Chem. 1 (2001) F4.3.1-F4.3.8, http://dx.doi.org/10. 1002/0471142913.faf0403s01.

[31] H. Sovová, Mathematical model for supercritical fluid extraction of natural products and extraction curve evaluation, J. Supercrit. Fluids 33 (2005) 35-52, http://dx.doi.org/10.1016/j.supflu.2004.03.005.

[32] M. Perrut, J.Y. Clavier, M. Poletto, E. Reverchon, Mathematical modeling of sunflower seed extraction by supercritical CO2, Ind. Eng. Chem. Res. 36 (1997) 430-435.

[33] J.C. de la Fuente, B. Oyarzún, N. Quezada, J.M. del Valle, Solubility of carotenoid pigments (lycopene and astaxanthin) in supercritical carbon dioxide, Fluid Phase Equilib. 247 (2006) 90-95, http://dx.doi.org/10.1016/j. fluid.2006.05.031.

[34] E. Günerken, E. D’Hondt, M.H.M. Eppink, L. Garcia-Gonzalez, K. Elst, R.H Wijffels, Cell disruption for microalgae biorefineries, Biotechnol. Adv. 33 (2015) 243-260, http://dx.doi.org/10.1016/j.biotechadv.2015.01.008.

[35] E. D’Hondt, J. Martín-Juárez, S. Bolado, J. Kasperoviciene, J. Koreiviene, S. Sulcius, K. Elst, L. Bastiaens, Cell disruption technologies, in: Microalgae-Based Biofuels and Bioproducts, Elsevier, 2017, pp. 133-154, http://dx.doi.org/10.1016/B978-0-08-101023-5.00006-6.

[36] Z. Wang, Q. Zhou, H. Guo, P. Yang, W. Lu, Determination of water solubility in supercritical CO2 from 313.15 to $473.15 \mathrm{~K}$ and from 10 to $50 \mathrm{MPa}$ by in-situ quantitative Raman spectroscopy, Fluid Phase Equilib. 476 (2018) 170-178, http://dx.doi.org/10.1016/j.fluid.2018.08.006. 